\title{
Effects of High-Temperature Stress during Plant Cultivation on Tomato (Solanum lycopersicum L.) Fruit Nutrient Content
}

\author{
Hayriye Yildiz Dasgan ${ }^{(D,},{ }^{1}$ Sultan Dere, ${ }^{2}$ Yelderem Akhoundnejad, ${ }^{3}$ \\ and Bekir Bülent Arpaci ${ }^{1}$ \\ ${ }^{1}$ Cukurova University, Agricultural Faculty, Department of Horticulture, Adana, Turkey \\ ${ }^{2}$ Siirt University, Agricultural Faculty, Department of Horticulture, Siirt, Turkey \\ ${ }^{3}$ Sirnak University, Agricultural Faculty, Department of Horticulture, Sirnak, Turkey \\ Correspondence should be addressed to Hayriye Yildiz Dasgan; ydasgan@gmail.com
}

Received 24 June 2021; Revised 1 September 2021; Accepted 25 October 2021; Published 30 November 2021

Academic Editor: Alessandra Durazzo

Copyright (c) 2021 Hayriye Yildiz Dasgan et al. This is an open access article distributed under the Creative Commons Attribution License, which permits unrestricted use, distribution, and reproduction in any medium, provided the original work is properly cited.

\begin{abstract}
Agriculture is among the sectors that will be impacted first and most by the adverse effects of climate change. Therefore, developing new high-temperature tolerant varieties is an essential economic measure in adaptation to near-future climate change. Likewise, there is a growing interest in increasing the antioxidant content of crops to improve food quality and produce crops with high-stress tolerance. Tomato is the most grown and consumed species in horticultural plants; however, it is vulnerable to $35^{\circ} \mathrm{C}$ and above high temperatures during cultivation. This study used twenty high-temperature tolerant, two susceptible genotypes, and two commercial tomato varieties in the open field. The experiment was applied under control and high-temperature stress conditions based on a randomized block design with 4 replications and 12 plants per repetition. The study investigated the fruit's selected quality properties and antioxidant compounds, namely, total soluble solutes (Brix), titratable acidity, pH, electrical conductivity (EC), lycopene, $\beta$-carotene, and vitamin $\mathrm{C}$, along with total phenols and total flavonoids under control and stress conditions. As a result, in general, total soluble solutes, titratable acidity, total phenol, and vitamin $\mathrm{C}$ contents under high-temperature conditions were determined to increase in tolerant tomato genotypes, while decreases were noted for $\mathrm{pH}, \mathrm{EC}$, total flavonoids, lycopene, and $\beta$-carotene. However, different specific responses on the basis of genotypes and useful information for breeding studies have been identified. These data on fruit nutrient content and antioxidants will be helpful when breeding tomato varieties to be grown in high-temperature conditions.
\end{abstract}

\section{Introduction}

Agriculture is predicted to be one of the sectors that are adversely affected by climate change, which is expected to be more pronounced in the upcoming years [1-4]. The agricultural sector has a fragile structure, directly dependent on climatic events. Therefore, studies and measures taken to minimize the possible adverse effects of climate change in developed countries are regarded as "important economic concepts" $[4,5]$. Furthermore, Turkey is located in the geographic zone where the adverse effects of climate change are inevitable. Consequently, it is vital that countries, including Turkey, combat climate change, reduce uncertainties, avoid possible adverse effects, and create strategies in this direction. In this sense, it is of paramount importance to choose plant genotypes tolerant to high-temperature stress, develop reliable and applicable methods and techniques, create and identify breeding materials, and cultivate new varieties for plant production.

Tomato is one of the most extensively grown and consumed horticultural crops. One of the factors that increase its consumption is its both fresh market and processed use. Furthermore, tomato fruit contains many essential nutrients such as phenols, flavones, carotenoids, vitamin $C$, vitamin $A$, potent antioxidants, minerals such as potassium, phosphorus, calcium, iron, and folic acid $[6,7]$. In addition, lycopene, which gives the tomato its red color, serves as a great protector of human health in various ways. 
These are abundant both in the tomato itself and in processed products, including tomato juice, tomato paste, ketchup, and all kinds of tomato sauces [7].

High temperature is significant environmental stress that limits plant growth and agricultural productivity. Moreover, the tomato is one of the primary species that is highly susceptible to elevated temperatures. Optimum temperatures for the development of flower organs, pollen, and fruit sets are between 15 and $32^{\circ} \mathrm{C}$, and temperatures of $35^{\circ} \mathrm{C}$ and above directly distress vegetative and generative development $[2,4,8]$. Likewise, temperature changes disturb the plant morphology, anatomy, phonology, and biochemistry at all organizational levels. High temperature directly causes protein denaturation and leads to increased fluidity of membrane lipids, inactivation of enzymes in chloroplasts and mitochondria, and disruption of membrane integrity in plants [9]. In addition, high-temperature stress in plants is associated with the production of reactive oxygen species (ROS) such as hydrogen peroxide, singlet oxygen, superoxide, and hydroxyl radical, and ROS accumulation is the leading source of crop loss $[10,11]$.

In Mediterranean countries, where summer temperatures are high $\left(35-45^{\circ} \mathrm{C}\right)$, tomato cultivation is restricted with decreased yield and product quality. Tomato production stops in these regions at the end of June and at the beginning of July. As the possible impact of global warming and climate change in the coming decades becomes more evident in these regions, there is concern that the current short vegetation period will be shortened even more $[2,4]$.

It was revealed that the stomata's closing under stress in tomatoes raised the leaf temperature and decreased photosynthesis [12]. Similarly, stomata were observed to reopen once the leaf temperature dropped, and the plants continued to develop by maintaining the normal functioning of photosynthesis under these conditions [12]. Also, Zhang et al. [13] reported that high temperatures reduced photosynthesis and tomato yield in the greenhouse. Additionally, Zhang et al. [14] stated that, compared to the control group, in plants exposed to $35^{\circ} \mathrm{C}$, net photosynthesis rates decreased, yet stomatal conductivity, intercellular $\mathrm{CO}_{2}$ concentration, and transpiration rate increased. Furthermore, in high-temperature stress conditions, decreases in the number of leaves are likely to be observed due to slow plant growth since the greater total number of leaves and thus the greater surface area would result in a more significant amount of water lost by transpiration. Lastly, it was emphasized that plants keep their stomata closed as much as possible under high-temperature stress and try to stop water loss by minimizing transpiration via shrinking leaf areas [15].

Curuk and Abak [16] determined tolerant genotypes in their study investigating the adaptation of high-temperature and humid-hot conditions tolerant tomato genotypes in summer in the Mediterranean climate. Another study emphasized that criteria such as the percentage of fruit with seeds, the amount of parthenocarpic fruit production, and the rate of aborted flowers can be reliable in determining the tolerance to high temperature in tomatoes [17].

It was reported that an increase in the temperature from $21^{\circ} \mathrm{C}$ to $26^{\circ} \mathrm{C}$ in tomato cultivation reduces the total carotene content but does not affect the lycopene content; meanwhile, an increase in temperature from $27^{\circ} \mathrm{C}$ to $32^{\circ} \mathrm{C}$ reduces the ascorbate and lycopene content; however, it enhances the routine caffeic acid derivatives and glucoside contents [18]. In addition, $\mathrm{F}_{1}$ hybrids containing mutants such as alcobaca (alc), ripening inhibitor (rin), and nonripening (nor), which provide fruit firmness in tomatoes, can relatively preserve properties such as color, texture, flavor, and nutritional quality under high-temperature settings [19].

Temperature influences assimilation, transport, and storage during fruit development. Structural and functional compounds such as starch, and secondary metabolites that influence the internal quality, are synthesized during the stages of fruit ripening [20]. The dry matter of the fruit comes from the assimilated photosynthesized in the leaves and then transported to the fruit as sucrose. The transformation of sucrose and other sugars into organic acids and aroma compounds determines tomatoes' taste. Environmental conditions affecting photosynthesis, temperature, and water irradiation also affect fruit quality [20].

Although there are many studies on physiology, plant growth, and yield of tomatoes under high-temperature conditions [21-28], there is limited research [29] on the nutrient and antioxidant content of the fruit affected by high temperatures. Also, there is a growing interest in increasing the antioxidant content of agricultural crops to improve food quality and produce crops with high-stress tolerance. A tomato can be one of the primary established sources of antioxidants in the human diet as its daily consumption is relatively high as fresh or processed. High-temperature stress may increase the antioxidant capacity of plants/fruits to scavenge ROS (reactive oxygen species) products in tolerant genotypes. Therefore, this study investigated tomato genotypes known to be tolerant to high-temperature stress, comparing them to commercial cultivars under stress and control conditions for variation in fruit nutrients and antioxidant contents in a region with the Mediterranean hot climate.

\section{Materials and Methods}

This study was carried out in Adana $\left(\left(37^{\circ} 01^{\prime} 49.1^{\prime \prime} \mathrm{N}\right.\right.$ $35^{\circ} 22^{\prime} 03.0^{\prime \prime} \mathrm{E}$, and elevation $23 \mathrm{~m}$ ) in the open field trial area of Cukurova University Faculty of Agriculture, Department of Horticulture, in 2016. The recorded climatic values in the trial area with a typical Mediterranean climate are shown in Figure 1 and Table 1 . Twenty genotypes with different tolerance levels for high temperature selected from a previous study [2] were used, and a total of twenty-four tomatoes, including two susceptible genotypes and two commercial cultivars, were studied (Table 2 and Figure 2). One of the most grown commercial cultivars in the region was the hybrid cultivar Hazera $56 \mathrm{~F}_{1}$, and the other was the standard open-pollinated cultivar H-2274. All tomatoes used in the experiment were determinate genotypes, and they are consumed as fresh market or processing. Detailed information (name/accession no, country of origin, fruit size, fruit shape, and product destination) about genotypes was presented in Table 2. 


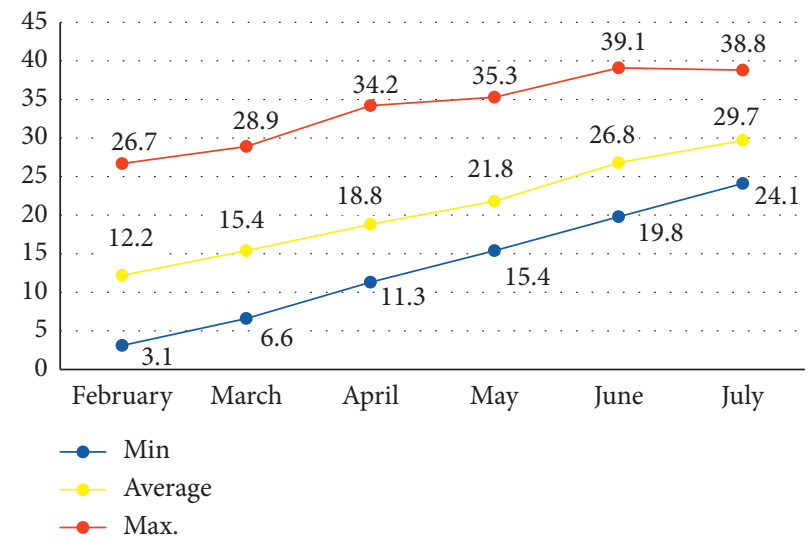

FIGURE 1: The minimum, maximum, and average air temperature values recorded in the trial area during the control and high-temperature stress trials $\left({ }^{\circ} \mathrm{C}\right)$ in the year 2016.

TABLE 1: Monthly average meteorological data recorded in the trials area during 2016.

\begin{tabular}{|c|c|c|c|c|}
\hline Meteorological data & April & May & June & July \\
\hline $10 \mathrm{~cm}$ soil temperature $\left({ }^{\circ} \mathrm{C}\right)$ & 18.74 & 27.52 & 31.56 & 34.28 \\
\hline $20 \mathrm{~cm}$ soil temperature $\left({ }^{\circ} \mathrm{C}\right)$ & 18.32 & 26.7 & 30.87 & 33.4 \\
\hline $50 \mathrm{~cm}$ soil temperature $\left({ }^{\circ} \mathrm{C}\right)$ & 17.76 & 24.4 & 29.13 & 31.44 \\
\hline $100 \mathrm{~cm}$ soil temperature $\left({ }^{\circ} \mathrm{C}\right)$ & 17.37 & 21.51 & 26.22 & 28.13 \\
\hline Relative humidity (\%) & 66.0 & 56.6 & 67.7 & 64.4 \\
\hline Precipitation $(\mathrm{mm})$ & 1.95 & 0.05 & 0.43 & 0.00 \\
\hline Sunshine duration (hours/day) & 9.78 & 10.14 & 11.27 & 9.54 \\
\hline
\end{tabular}

TAвLE 2: Genotypes of tomato used in studies: high-temperature tolerant and susceptible genotypes and commercial tomato varieties* .

\begin{tabular}{|c|c|c|c|c|c|}
\hline Tolerant genotypes & Name/accession no & Country of origin & Fruit size & Fruit shape & Product destination \\
\hline Tom-12 & Rio Grande & Turkey & Medium $(85-105 \mathrm{~g})$ & Oval & Processing \\
\hline Tom-14 & Cambell33 & Turkey & Medium (76-96 g) & Flattened globe & Fresh market/processing \\
\hline Tom-19 & Roza & France & Big (136-158g) & Round & Fresh market \\
\hline Tom-20 & $1071-33^{\mathrm{a}}$ & Turkey & Big $(180-205 \mathrm{~g})$ & Round & Fresh market \\
\hline Tom-26 & $1009-6^{\mathrm{a}}$ & Turkey & Big $(110-130 \mathrm{~g})$ & Round & Fresh market \\
\hline Tom-40 & $227 / 1^{\mathrm{a}}$ & Turkey & Big $(120-138 \mathrm{~g})$ & Round & Fresh market \\
\hline Tom-47 & Red Cherry & USA & Small (13-25 g) & Cherry & Fresh market \\
\hline Tom-108 & Pakmor & Turkey & Big (190-212 g) & Round-oval & Fresh market/processing \\
\hline Tom-111 & TridoraRHT1 & France & Medium (90-105 g) & Round-oval & Fresh market/processing \\
\hline Tom-114 & LignonS5RHT8 & France & Big (135-150g) & Round & Fresh market \\
\hline Tom-115 & LignonS2RHT9 & France & Big $(135-165 \mathrm{~g})$ & Flattenet & Fresh market \\
\hline Tom-119 & AdanaYerliRHT14 ${ }^{\mathrm{a}}$ & Turkey & Small $(45-55 \mathrm{~g})$ & Round & Fresh market \\
\hline Tom-165 & ${\text { TR } 62573^{\mathrm{a}}}$ & Turkey & $\operatorname{Big}(98-110 \mathrm{~g})$ & Oval & Fresh market/processing \\
\hline Tom-173 & $\operatorname{TR} 2361^{\mathrm{a}}$ & Turkey & Small $(12-20 \mathrm{~g})$ & Cherry & Fresh market \\
\hline Tom-201-B & Bishkek-1 & Kyrgyzstan & Small $(40-45 \mathrm{~g})$ & Small pear & Fresh market \\
\hline Tom-211 & Bishkek-2 & Kyrgyzstan & Big (145-160 g) & Round & Fresh market \\
\hline Tom-225 & CLN3126A-7 & AVRDC & Medium (65-78 g) & Oval & Processing \\
\hline Tom-230 & CLN3125O & AVRDC & Medium (85-95 g) & Oval & Processing \\
\hline Tom-232 & CLN3078C & AVRDC & Small $(40-50 \mathrm{~g})$ & Oval & Processing \\
\hline Tom-233 & CLN3078G-AV & AVRDC & Small 45-55 g) & Oval & Processing \\
\hline \multicolumn{6}{|l|}{ Susceptible genotypes } \\
\hline Tom-175 & $\operatorname{TR} 52377^{\mathrm{a}}$ & Turkey & Small (16-25g) & Cherry & Fresh market \\
\hline Tom-116 & LignonS1RHT10 & France & Medium (60-65 g) & Round & Fresh market/processing \\
\hline \multicolumn{6}{|l|}{ Commercial cultivars } \\
\hline Hazera56 $\mathrm{F}_{1}$ & Hazera56 F1 & Israel & Big $(140-180 \mathrm{~g})$ & Round & Fresh market \\
\hline H-2274 & H-2274 & Turkey & Big $(110-150 \mathrm{~g})$ & Round-oval & Fresh market/processing \\
\hline
\end{tabular}

${ }^{a}$ Germplasm collections maintained at Turkish public institution. ${ }^{*}$ Measured properties of tomatoes were recorded in the experimental ecological conditions.

In the spring-summer growing period, two separate trials were established as "control" and "high temperature" in two different periods with planting time adjustments. The first trial was the control trial following the tomato planting schedule in the region. The control trial seeds were sown on 27 February 2016 in vials containing a $2: 1$ sphagnum peat 

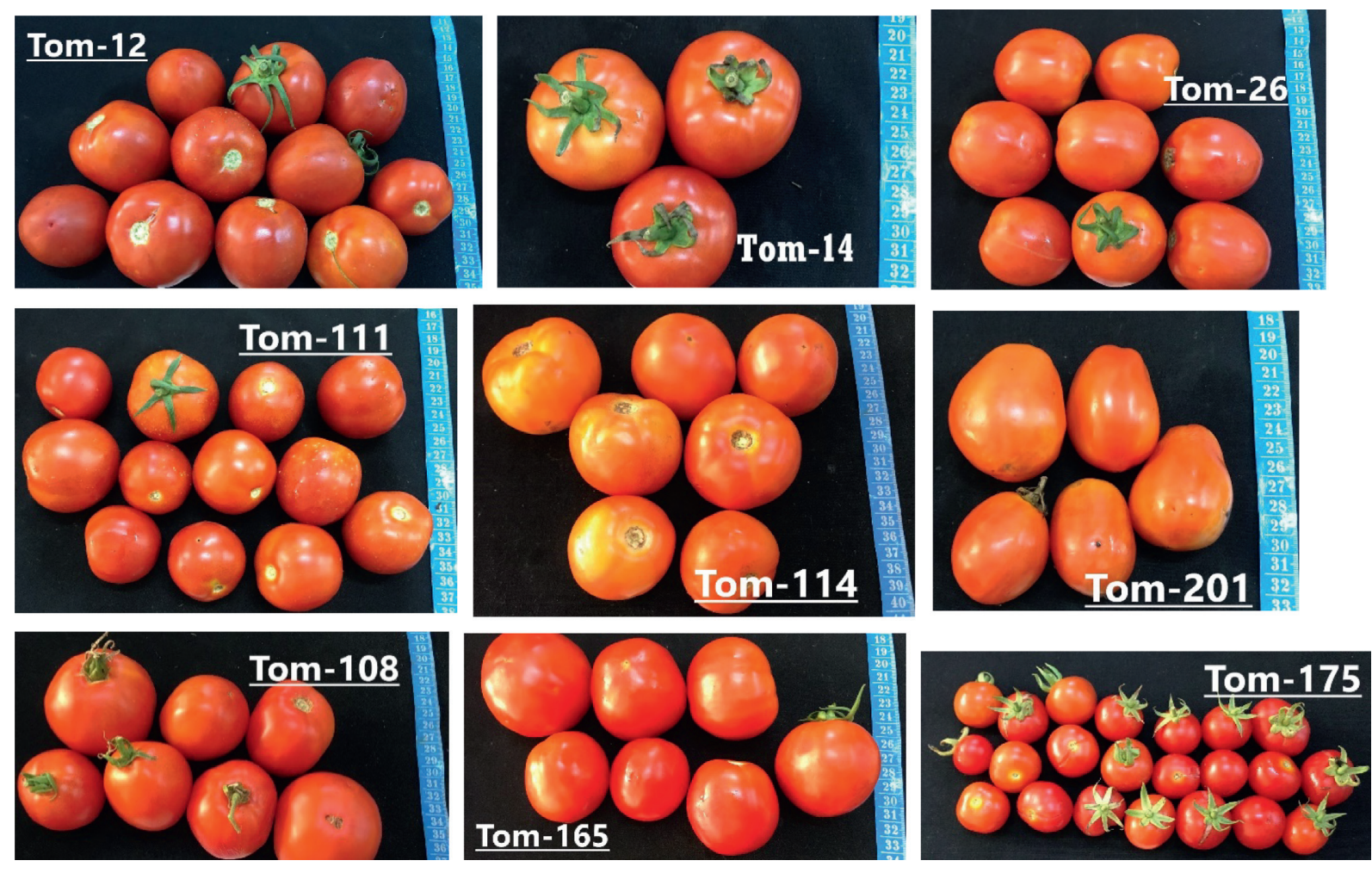

Figure 2: Fruits of some tomato genotypes used in the study.

moss: perlite mixture. Sphagnum peat moss chemical components consisted of lime, mineral NPK fertilizer, and wetting agent. The seedlings were grown in a glasshouse, and daytime temperatures ranged between 23 and $25^{\circ} \mathrm{C}$ while they were $14-16^{\circ} \mathrm{C}$ at night. The seedlings were planted into the field at the stage of five true leaves on 14 April 2016, and plants were grown in the field in April-May-June. In the control trial, the tomato fruit sampling date was 15 June 2016. In the high-temperature experiment, the seeds were sown on 22 April 2016, and they were grown in a glasshouse. During the growing process, temperatures were $26-29^{\circ} \mathrm{C}$ during the day and $18-20^{\circ} \mathrm{C}$ at night. The seedlings were planted on the stage of five true leaves into the field one month later, on 22 May 2016. In the second experiment, tomato plants' vegetative and generative growth stages were exposed to high temperatures in the region (Figure 1). Tomato fruits were sampled on 25 July 2016 in the stress trial. Both trials were set up in a randomized block experimental design with 4 replications and 12 plants in each replication. Prior to the experiments, soil analysis at a depth of $0-30 \mathrm{~cm}$ revealed that soil was composed of clay loam with $\mathrm{pH} 7.48$, EC $0.21, \mathrm{CaCO}_{3} 21.23 \%$, and organic matter $2.02 \%$. Mineral nutrient levels of the soil were insignificant. Plant spacing was arranged as $120 \mathrm{~cm} \times 50 \mathrm{~cm}$. Fertigation and irrigation of tomato plants were applied following Akhoundnejad et al. [30] as $16 \mathrm{~kg} \mathrm{~N}, 5 \mathrm{~kg} \mathrm{P}_{2} \mathrm{O}_{5}, 23 \mathrm{~kg} \mathrm{~K} \mathrm{~K}_{2} \mathrm{O}$, $10 \mathrm{CaO}$, and $12 \mathrm{MgO}$. According to the temperature values in Figure 1, during the stress experiment, the maximum temperatures reached $35.3^{\circ} \mathrm{C}, 39.1^{\circ} \mathrm{C}$, and $38.8^{\circ} \mathrm{C}$ in May, June, and July, respectively (Figure 1). These temperature values are high enough to stress the tomato plant. In addition, the monthly average soil temperature, precipitation amount, air humidity, and sunshine duration data of the trial area were shown in Table 1. Cultivation continued until several fruit clusters were harvested (5 harvests) and tomatoes were harvested at the red ripe stage. In both trials, there were 4 replications in the field and 4 biological samples taken from the 2 nd harvest. Each of the biologic samples consisted of 10 fruits. All extracts were from four biological replicates, and two technical assays were carried out on each biological repetition.

2.1. Total Soluble Solids (TSSs). The amounts of total soluble solids (Brix) in tomato fruits were determined by a digital refractometer ATAGO PR-32 (ATAGO USA Inc., Kirkland, WA, USA). Results were expressed as \%.

2.2. Titratable Acidity. $5 \mathrm{ml}$ of tomato juice was completed to $50 \mathrm{ml}$ with distilled water and titrated with $0.1 \mathrm{~N} \mathrm{NaOH}$ up to 8.1 with the help of a digital $\mathrm{pH}$ meter, and the values were calculated in terms of citric acid [31].

2.3. Vitamin C (L-Ascorbic Acid) Content. After the tomato fruits were pureed with a blender, $1 \mathrm{ml}$ of fruit juice was taken with an automatic pipette, and $4 \mathrm{ml}$ of $3 \%$ metaphosphoric acid was added and vortexed for 1 minute. It was then shaken for 15 minutes. Next, passing the upper phase of the samples through $0.45 \mu \mathrm{m}$ and $47 \mathrm{~mm}$ diameter filters, the HCPL was read according to Bozan et al. [32]. 
2.4. pH Measurement. It was measured with a WTW brand and 3110 model $\mathrm{pH}$ meter in $100 \mathrm{ml}$ of tomato juice.

2.5. EC Measurement. It was measured with a WTW brand and 3310 model EC meter in $100 \mathrm{ml}$ of tomato juice.

2.6. Total Phenol Content Determination (TPC). After the fruits were pureed with a blender, $50 \mu \mathrm{l}$ of fruit juice was taken with an automatic pipette, $3.9 \mathrm{ml}$ of distilled water, and $250 \mu \mathrm{l}$ of phenol chemical was added and vortexed for 1 minute. Then, $750 \mu \mathrm{l}$ of $20 \%$ sodium carbonate was added to a 1-minute vortexed sample and vortexed for the second time for 1 minute. After the vortexed samples were kept in the dark environment for 2 hours, $250 \mu \mathrm{l}$ was collected from the samples, added to the spectrophotometer plates, and read at $760 \mathrm{~nm}$ wavelength according to Spanos and Wrolstad [33].

2.7. Total Flavonoid Content Determination. After the fruits were pureed with a blender, $200 \mu \mathrm{l}$ of fruit juice was taken with an automatic pipette, $200 \mu \mathrm{l}$ of $2 \% \mathrm{AgCl}_{3}$, and $4.6 \mathrm{ml}$ of ethyl alcohol was added and vortexed for 1 minute. Then, the vortexed samples were covered with aluminum foil and were water showered for 40 minutes at $20^{\circ} \mathrm{C}$. Finally, $250 \mu \mathrm{l}$ of the samples was collected, added to the spectrophotometer plates, and read at a wavelength of $415 \mathrm{~nm}$ according to the method developed by Quettier-Deleu et al. [34].

\subsection{Carotenoid Component Analysis in Fruit: Lycopene and} $\beta$-Carotene. After the fruits were pureed with a blender, $1 \mathrm{ml}$ of fruit juice was taken with an automatic pipette, and $8 \mathrm{ml}$ of chloroform was added and vortexed for 1 minute. Then, the vortexed samples were shaken in a shaker for 15 minutes. Finally, the samples taken from the shaker were centrifuged at $5500 \mathrm{rpm}$ for 5 minutes. The upper phase of the centrifuged samples was collected with a syringe, passed through filters of $0.45 \mu \mathrm{m}$ and $47 \mathrm{~mm}$ in diameter, and put into HCPL bottles. Lycopene and $\beta$-carotene values were determined by using Intersil ODS-2 $(250 \times 4.6 \mathrm{~mm}, 5 \mu \mathrm{m}$ ID) column UV detector by modifying the methods suggested by Sadler et al. [35] and Ozkan [36]. Lycopene obtained from the chromatograms was defined by comparing the arrival times and UV spectra of the standard substances, and the amounts of lycopene and $\beta$-carotene in the samples were calculated using the standard curves prepared with the standards of these components.

2.9. Statistical Analysis. In both control and stress trials, there were 4 replications in the field and 4 biological samples taken from the 2nd tomato harvest. Each of the biologic samples consisted of 10 fruits. All extracts were from four biological replicates, and two technical assays were carried out on each biological repetition. In control and stress trials, variance (ANOVA) tests with one-factor analysis using JMP statistical software were applied for fruit data analysis. The means were compared with the least significant difference (LSD) test at the significance level of 0.05 . The variation of nutrient contents in tomato fruit at high-temperature stress compared to the control was calculated and expressed in percent. Matched pairs $t$-test was used to evaluate the effect of high-temperature and control conditions on tolerant, susceptible tomato genotypes and commercial varieties. All of the independent variables were subjected to principal component analysis (PCA), multiple variable analysis by the Pearson correlation matrix, and a heat map was constructed using correlation distance and average linkage by ClustVis software (https://biit.cs.ut.ee/clustvis/).

\section{Results and Discussion}

3.1. Total Soluble Solids of Tomatoes. Total soluble solids (TSSs) in tomato fruit generally increased under high temperatures. TSS content of the genotypes was significantly influenced by high temperature compared by paired $t$-test $(P<0.0261)$ with the control (Figure 3(a)). The mean increase in TSS under stress for all genotypes was $5.04 \%$. The mean increases for tolerant and susceptible genotypes were $5.17 \%$ and $3.95 \%$, respectively. The TSS increase rate of commercial varieties was $4.88 \%$ (Table 3 ). Compared to the control, the highest increase in stress was determined in the Tom-165 genotype with $22.98 \%$, followed by Tom-19, Tom211 , and Tom- 114 with $21 \%, 17.85 \%$, and $13.68 \%$, respectively. There was a $16.94 \%$ decrease in the Tom-20 genotype. While there was an increase of $5.98 \%$ in Hazera $\mathrm{F}_{1}$ and $3.77 \%$ in H-2274 from commercial cultivars regarding TSS, a $10.93 \%$ increase in Tom-116 and 3.03\% decrease in Tom-175 were determined in susceptible genotypes (Table 3, Figure 3(a)). When the tolerant genotypes were compared with the commercial tomato cultivars, the increase in TSS was higher at high temperatures.

Total soluble solid is an essential indicator of tomato fruit's taste and flavor [37]. The main reason for the change in TSS content in tomato fruit is the decrease in glucose/ fructose ratio and changes in organic acid content. Khanal et al. [38] reported that in different day/night temperature regimes $\left(24 / 17,27 / 14\right.$, and $\left.30 / 11^{\circ} \mathrm{C}\right)$, the amount of TSS in tomatoes increased as the temperature increased. Zhou et al. [39] also stated that glucose, sucrose, and fructose increase in tomato leaves under high-temperature stress. Likewise, in other studies, the TSS content in tomato genotypes was reported to have increased compared to the control under high-temperature stress $[40,41]$. Nonetheless, along with TSS content, the total sugar content decreased in hightemperature stress compared to the control, but this decrease was slighter in tolerant genotypes [41]. Although it depends on the genotype, it may be said that the high temperatures in this study did not hinder the transport and storage of photoassimilates to the fruit since TSS mainly was higher than the control tomatoes (Table 3).

3.2. Titratable Acidity of Tomatoes. The differences of titratable acidity data of the tomato genotypes under hightemperature and control conditions were confirmed by paired $t$-test $(P<0.0025)$ and are presented in Figure 3(b). The mean increase in titratable acidity in all genotypes was $6.76 \%$. The 


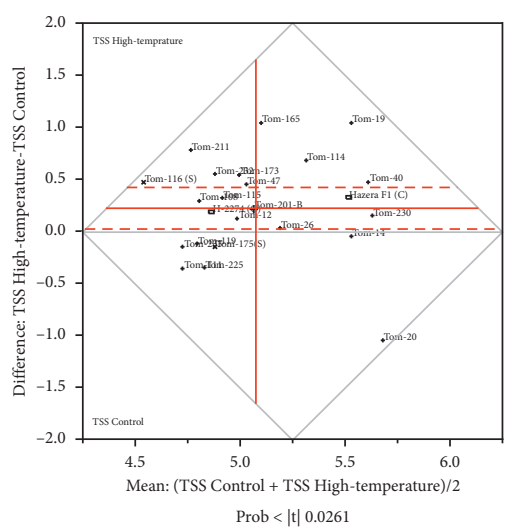

(a)

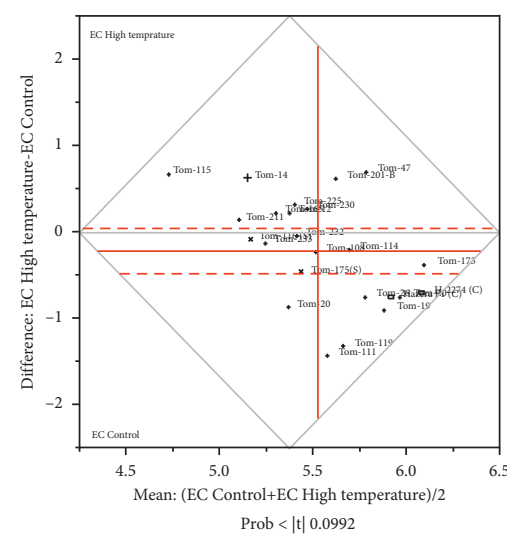

(d)

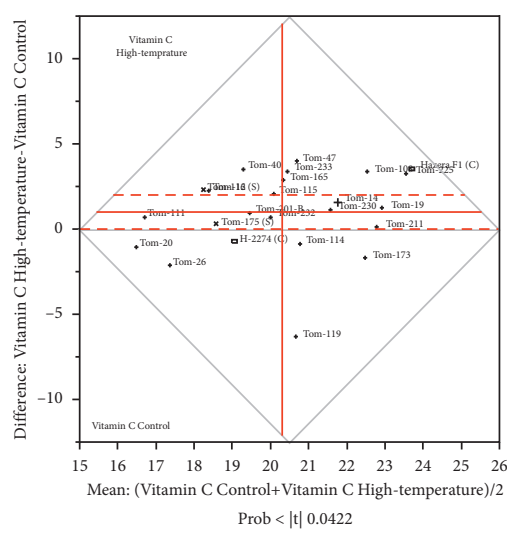

(g)

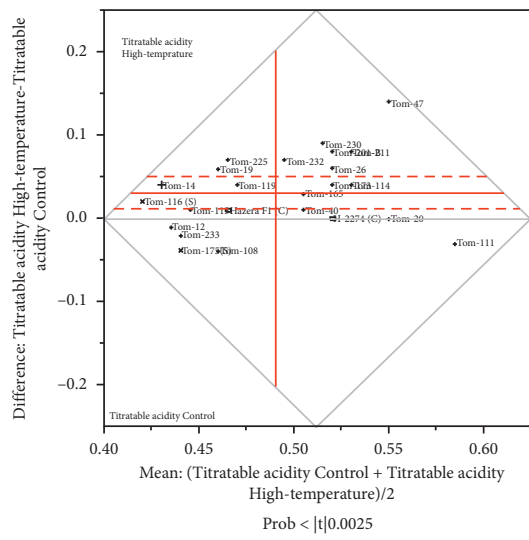

(b)

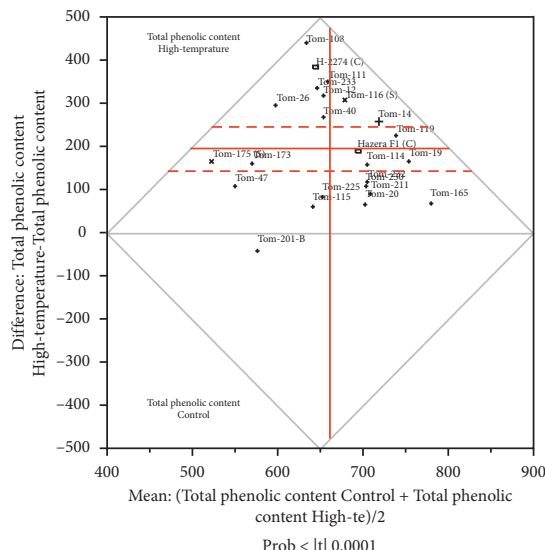

(e)

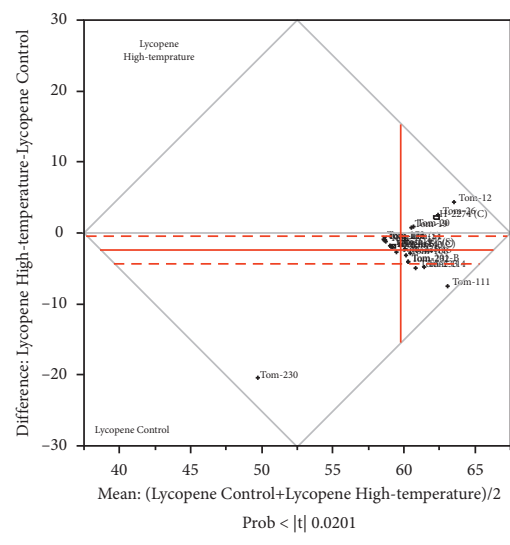

(h)

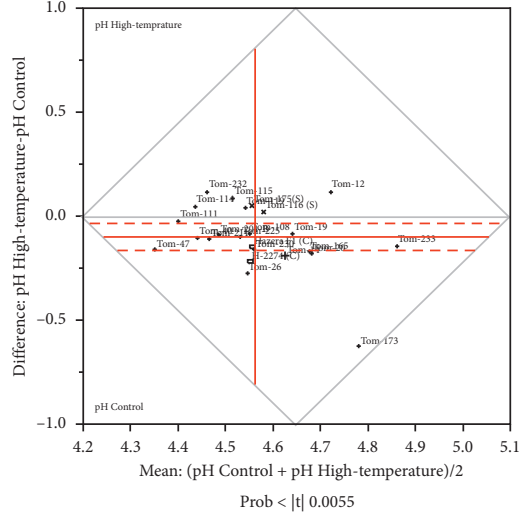

(c)

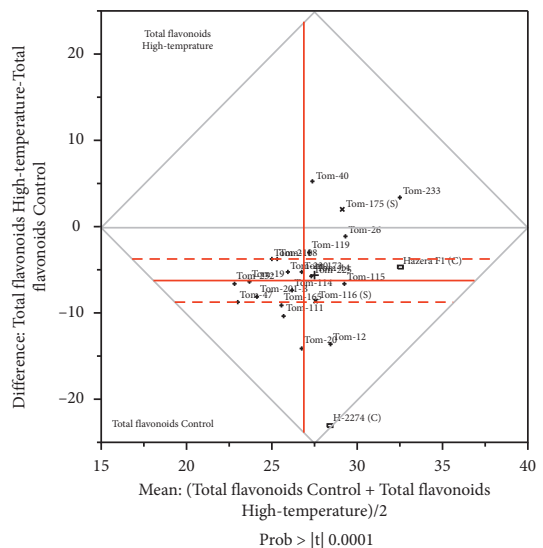

(f)

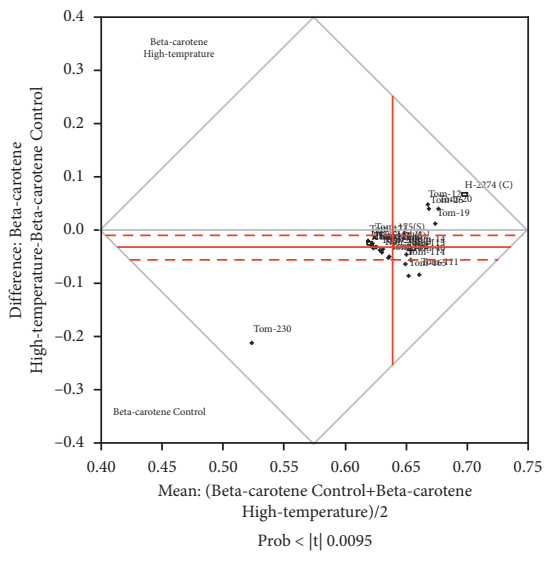

FiguRE 3: Comparison of high-temperature stress by paired $t$-test: total soluble solids: (a) titratable acidity, (b) pH, (c) EC, (d) total phenols, (e) total flavonoid, (f) vitamin C, (g) lycopene, (h) beta-carotene, and (i) content. +tolerant, xsusceptible $\square$ commercial.

average increase in tolerant genotypes and commercial varieties was $8.19 \%$ and $1.09 \%$, respectively. However, there was a mean decrease of $1.91 \%$ in susceptible genotypes (Table 4 ). Tom-47 genotype showed the highest increase with $29.17 \%$, while Tom-108 showed the highest decrease with $8.33 \%$. While there was no change in the commercial variety $\mathrm{H}-2274$, there was an increase of $2.17 \%$ in Hazera $F_{1}$. The increase in acidity in table tomatoes is significant to increase the eating quality. Acidity increase was determined in other genotypes except for Tom-108, Tom-111, Tom-223, and Tom-12, which are tolerant genotypes (Figure 3(b)). Many studies reported that the ratio of acid to sugars is vital in determining tomato fruit flavor [42, 43]. Temperature-related stress affects fruit maturity and growth by regulating acid invertase and sucrose synthase enzyme regulation and sugar transport in tomatoes $[41,44]$. In this study, acidity varied between 0.41 and $0.60 \mathrm{~g}$

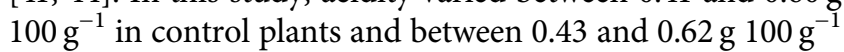
under stress conditions. Khanal [45] stated that titratable

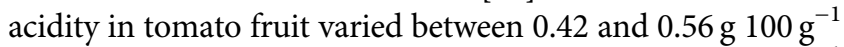

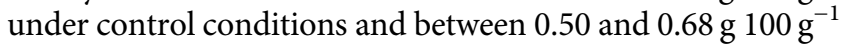
under stress conditions grown under control and hightemperature stress. 
TABLE 3: Total soluble solids (Brix) of tomato fruits in control and high-temperature stress (\%).

\begin{tabular}{|c|c|c|c|}
\hline Tolerant & Control & $\begin{array}{c}\text { High } \\
\text { temperature }\end{array}$ & $\begin{array}{c}\text { Relative change } \\
(\%)\end{array}$ \\
\hline Tom-12 & $4.92 \mathrm{c}-\mathrm{e}$ & $5.05 \mathrm{c}-\mathrm{f}$ & 2.6 \\
\hline Tom-14 & $5.55 \mathrm{~b}$ & $5.50 \mathrm{a}-\mathrm{e}$ & -0.9 \\
\hline Tom-19 & $5.00 \mathrm{c}-\mathrm{e}$ & $6.05 \mathrm{a}$ & 21.0 \\
\hline Tom-20 & $6.20 \mathrm{a}$ & $5.15 \mathrm{~b}-\mathrm{f}$ & -16.9 \\
\hline Tom-26 & $5.17 \mathrm{~b}-\mathrm{d}$ & $5.20 \mathrm{~b}-\mathrm{f}$ & 0.6 \\
\hline Tom-40 & $5.37 \mathrm{bc}$ & $5.85 \mathrm{ab}$ & 8.9 \\
\hline Tom-47 & $4.80 \mathrm{~d}-\mathrm{g}$ & $5.25 \mathrm{~b}-\mathrm{f}$ & 9.4 \\
\hline Tom-108 & $4.65 \mathrm{~d}-\mathrm{g}$ & $4.95 \mathrm{~d}-\mathrm{f}$ & 6.5 \\
\hline Tom-111 & $4.90 \mathrm{c}-\mathrm{f}$ & $4.55 \mathrm{f}$ & -7.1 \\
\hline Tom-114 & $4.97 \mathrm{c}-\mathrm{e}$ & $5.65 \mathrm{a}-\mathrm{d}$ & 13.7 \\
\hline Tom-115 & $4.75 \mathrm{~d}-\mathrm{g}$ & $5.07 \mathrm{c}-\mathrm{f}$ & 6.7 \\
\hline Tom-119 & $4.85 \mathrm{c}-\mathrm{f}$ & 4.73 ef & -2.5 \\
\hline Tom-165 & $4.57 \mathrm{e}-\mathrm{g}$ & $5.62 \mathrm{a}-\mathrm{d}$ & 23.0 \\
\hline Tom-173 & $4.72 \mathrm{~d}-\mathrm{g}$ & $5.27 \mathrm{~b}-\mathrm{f}$ & 11.7 \\
\hline Tom-201-B & $4.95 \mathrm{c}-\mathrm{e}$ & $5.17 \mathrm{~b}-\mathrm{f}$ & 4.4 \\
\hline Tom-211 & $4.37 \mathrm{fg}$ & $5.15 \mathrm{~b}-\mathrm{f}$ & 17.9 \\
\hline Tom-225 & $5.00 \mathrm{c}-\mathrm{e}$ & $4.65 \mathrm{f}$ & -7.0 \\
\hline Tom-230 & $5.55 \mathrm{~b}$ & $5.70 \mathrm{a}-\mathrm{c}$ & 2.7 \\
\hline Tom-232 & $4.60 \mathrm{e}-\mathrm{g}$ & $5.15 \mathrm{c}-\mathrm{f}$ & 12.0 \\
\hline Tom-233 & $4.80 \mathrm{~d}-\mathrm{g}$ & $4.65 \mathrm{f}$ & -3.1 \\
\hline $\begin{array}{l}\text { Tolerant mean } \\
\text { Susceptible }\end{array}$ & & & 5.2 \\
\hline Tom-116 & $4.30 \mathrm{~g}$ & $4.77 \mathrm{ef}$ & 10.9 \\
\hline Tom-175 & $4.95 \mathrm{c}-\mathrm{e}$ & 4.80 ef & -3.0 \\
\hline Susceptible mean & & & 4.0 \\
\hline Commercial & & & \\
\hline Hazera $\mathrm{F}_{1}$ & $5.35 \mathrm{bc}$ & $5.67 \mathrm{a}-\mathrm{d}$ & 6.0 \\
\hline H-2274 & $4.77 \mathrm{~d}-\mathrm{g}$ & $4.95 \mathrm{~d}-\mathrm{f}$ & 3.8 \\
\hline $\begin{array}{l}\text { Commercial } \\
\text { mean }\end{array}$ & & & 4.9 \\
\hline Overall mean & 4.96 & 5.19 & 5.0 \\
\hline
\end{tabular}

Different letters in each column indicate significance $(P<0.05)$.

3.3. $\mathrm{pH}$ of Tomatoes. Fruit $\mathrm{pH}$ decreased by an average of $2.04 \%$ in all tomatoes under high-temperature stress. The differences of fruit $\mathrm{pH}$ between high-temperature and control conditions were found significant $(P<0.0055)$ compared by paired $t$-test (Figure 3(c)). Average decrease rates in tolerant genotypes and commercial cultivars were $2.13 \%$ and $3.98 \%$, respectively. In susceptible genotypes, the $\mathrm{pH}$ increased by an average of $0.77 \%$ (Table 5 ). The highest decrease in $\mathrm{pH}$ was found in the Tom-173 genotype with $12.18 \%$, and the highest increase in $\mathrm{pH}$ was found in the Tom-232 genotype with $2.73 \%$. $\mathrm{pH}$ decreases in Tom-111, Tom-19, Tom-108, Tom-201-B, Tom-225, Tom-211, and Tom-233 genotypes were less than commercial cultivars (Figure 3(c)). Khanal [45] reported that the $\mathrm{pH}$ of tomato fruit decreased as the temperature increased in the high day and low night temperatures of $27 / 14^{\circ} \mathrm{C}$ and $30 / 11^{\circ} \mathrm{C}$ regimes.

3.4. EC of Tomatoes. The EC value indicates the concentration of the total mineral elements. Therefore, an increase in EC in tomato fruit means an increase in the fruit's mineral content, which is desirable. The EC value of all tomatoes slightly decreased by an average of $2.98 \%$ under high temperatures; however, differences between
TABLE 4: Titratable acidity (in terms of citric acid) of tomato fruits grown under control and high-temperature stress ((g citric acid/ $100 \mathrm{ml}$ juice).

\begin{tabular}{|c|c|c|c|}
\hline Tolerant & Control & $\begin{array}{c}\text { High } \\
\text { temperature }\end{array}$ & $\begin{array}{c}\text { Relative change } \\
(\%)\end{array}$ \\
\hline Tom-12 & $0.44 \mathrm{f}-\mathrm{h}$ & 0.43 ef & -2.3 \\
\hline Tom-14 & $0.41 \mathrm{~h}$ & $0.45 \mathrm{~d}-\mathrm{f}$ & 9.8 \\
\hline Tom-19 & $0.43 \mathrm{gh}$ & $0.49 \mathrm{~b}-\mathrm{f}$ & 14.0 \\
\hline Tom-20 & $0.55 \mathrm{ab}$ & $0.55 \mathrm{a}-\mathrm{c}$ & 0.0 \\
\hline Tom-26 & $0.49 \mathrm{c}-\mathrm{e}$ & $0.55 \mathrm{a}-\mathrm{c}$ & 12.2 \\
\hline Tom-40 & $0.50 \mathrm{~b}-\mathrm{d}$ & $0.51 \mathrm{~b}-\mathrm{e}$ & 2.0 \\
\hline Tom-47 & $0.48 \mathrm{c}-\mathrm{f}$ & $0.62 \mathrm{a}$ & 29.2 \\
\hline Tom-108 & $0.48 c-f$ & $0.44 \mathrm{~d}-\mathrm{f}$ & -8.3 \\
\hline Tom-111 & $0.60 \mathrm{a}$ & $0.57 \mathrm{ab}$ & -5.0 \\
\hline Tom-114 & $0.51 \mathrm{bc}$ & $0.55 \mathrm{a}-\mathrm{c}$ & 7.8 \\
\hline Tom-115 & $0.44 \mathrm{e}-\mathrm{h}$ & $0.45 \mathrm{~d}-\mathrm{f}$ & 2.3 \\
\hline Tom-119 & $0.45 \mathrm{~d}-\mathrm{h}$ & $0.49 \mathrm{~b}-\mathrm{f}$ & 8.9 \\
\hline Tom-165 & $0.49 \mathrm{c}-\mathrm{e}$ & $0.52 \mathrm{~b}-\mathrm{d}$ & 6.1 \\
\hline Tom-173 & $0.50 \mathrm{~b}-\mathrm{d}$ & $0.54 \mathrm{a}-\mathrm{c}$ & 8.0 \\
\hline Tom-201-B & $0.48 \mathrm{c}-\mathrm{f}$ & $0.56 \mathrm{a}-\mathrm{c}$ & 16.7 \\
\hline Tom-211 & $0.49 \mathrm{c}-\mathrm{f}$ & $0.57 \mathrm{ab}$ & 16.3 \\
\hline Tom-225 & $0.43 \mathrm{gh}$ & $0.50 \mathrm{~b}-\mathrm{f}$ & 16.3 \\
\hline Tom-230 & $0.47 \mathrm{c}-\mathrm{g}$ & $0.56 \mathrm{a}-\mathrm{c}$ & 19.2 \\
\hline Tom-232 & $0.46 \mathrm{~d}-\mathrm{h}$ & $0.53 \mathrm{~b}-\mathrm{d}$ & 15.2 \\
\hline Tom-233 & $0.45 \mathrm{e}-\mathrm{h}$ & 0.43 ef & -4.4 \\
\hline Tolerant mean & & & 8.2 \\
\hline \multicolumn{4}{|l|}{ Susceptible } \\
\hline Tom-116 & $0.41 \mathrm{~h}$ & $0.43 \mathrm{ef}$ & 4.9 \\
\hline Tom-175 & $0.46 \mathrm{~d}-\mathrm{h}$ & $0.42 \mathrm{f}$ & -8.7 \\
\hline Susceptible mean & & & -1.9 \\
\hline \multicolumn{4}{|l|}{ Commercial } \\
\hline Hazera $\mathrm{F}_{1}$ & $0.46 \mathrm{~d}-\mathrm{h}$ & $0.47 \mathrm{c}-\mathrm{f}$ & 2.2 \\
\hline $\mathrm{H}-2274$ & $0.52 \mathrm{bc}$ & $0.52 \mathrm{~b}-\mathrm{d}$ & 0.0 \\
\hline $\begin{array}{l}\text { Commercial } \\
\text { mean }\end{array}$ & & & 1.1 \\
\hline Overall mean & 0.48 & 0.51 & 6.8 \\
\hline
\end{tabular}

Different letters in each column indicate significance $(P<0.05)$, FW: fresh weight.

under high-temperature and control conditions were not significant (paired $t$-test: $P<0.0992$ ) as presented in Figure 3(d). The mean EC declines in high-temperature tolerant, susceptible genotypes, and commercial cultivars were $1.92 \%, 5.01 \%$, and $11.56 \%$, respectively. The highest EC increase under stress was determined in the Tom-115 genotype with $15.26 \%$, and the highest EC decrease was found in the Tom-111 genotype with $22.73 \%$. A decrease of $12.08 \%$ was found in Hazera $F_{1}$ and $11.04 \%$ in the H-2274 variety (Table 6). Finally, changes in EC values were investigated depending on the tolerance and sensitivity of tomato plants to high-temperature stress. In plants under high-temperature stress, stomatal closure may reduce transpiration and water uptake and limit the uptake of minerals and water [2]. Rates of water and nutrient uptake by roots depend on solar radiation. High dependence on solar radiation on water uptake rate was reported [46]. Furthermore, nutrient uptake rates were also highly dependent on water uptake rates. High temperature and high radiation can often be found in combination. High-temperature stress may decrease the total protein concentration and nutrient uptake levels and 
TABLE 5: pH of tomato fruits grown under control and hightemperature stress.

\begin{tabular}{lccc}
\hline Tolerant & Control & $\begin{array}{c}\text { High } \\
\text { temperature }\end{array}$ & $\begin{array}{c}\text { Relative change } \\
(\%)\end{array}$ \\
\hline Tom-12 & $4.66 \mathrm{~b}-\mathrm{e}$ & $4.78 \mathrm{a}$ & 2.6 \\
Tom-14 & $4.72 \mathrm{~b}-\mathrm{e}$ & $4.53 \mathrm{~b}-\mathrm{e}$ & -4.0 \\
Tom-19 & $4.68 \mathrm{~b}-\mathrm{e}$ & $4.60 \mathrm{~b}$ & -1.7 \\
Tom-20 & $4.77 \mathrm{a}-\mathrm{c}$ & $4.59 \mathrm{~b}$ & -3.8 \\
Tom-26 & $4.68 \mathrm{~b}-\mathrm{e}$ & $4.41 \mathrm{gh}$ & -5.8 \\
Tom-40 & $4.49 \mathrm{c}-\mathrm{e}$ & $4.39 \mathrm{~h}$ & -2.2 \\
Tom-47 & $4.43 \mathrm{de}$ & $4.27 \mathrm{i}$ & -3.6 \\
Tom-108 & $4.59 \mathrm{c}-\mathrm{e}$ & $4.51 \mathrm{~b}-\mathrm{g}$ & -1.7 \\
Tom-111 & $4.41 \mathrm{e}$ & $4.39 \mathrm{~h}$ & -0.5 \\
Tom-114 & $4.41 \mathrm{e}$ & $4.46 \mathrm{~d}-\mathrm{h}$ & 1.1 \\
Tom-115 & $4.47 \mathrm{c}-\mathrm{e}$ & $4.56 \mathrm{~b}-\mathrm{d}$ & 2.0 \\
Tom-119 & $4.52 \mathrm{c}-\mathrm{e}$ & $4.56 \mathrm{~b}-\mathrm{d}$ & 0.9 \\
Tom-165 & $4.76 \mathrm{a}-\mathrm{d}$ & $4.59 \mathrm{~b}$ & -3.6 \\
Tom-173 & $5.09 \mathrm{a}$ & $4.47 \mathrm{c}-\mathrm{h}$ & -12.2 \\
Tom-201-B & $4.53 \mathrm{c}-\mathrm{e}$ & $4.44 \mathrm{e}-\mathrm{h}$ & -2.0 \\
Tom-211 & $4.52 \mathrm{c}-\mathrm{e}$ & $4.41 \mathrm{f}-\mathrm{h}$ & -2.4 \\
Tom-225 & $4.58 \mathrm{c}-\mathrm{e}$ & $4.48 \mathrm{c}-\mathrm{h}$ & -2.2 \\
Tom-230 & $4.64 \mathrm{~b}-\mathrm{e}$ & $4.48 \mathrm{c}-\mathrm{h}$ & -3.5 \\
Tom-232 & $4.40 \mathrm{e}$ & $4.52 \mathrm{~b}-\mathrm{f}$ & 2.7 \\
Tom-233 & $4.93 \mathrm{ab}$ & $4.79 \mathrm{a}$ & -2.8 \\
Tolerant mean & & & -2.1 \\
Susceptible & & & \\
Tom-116 & $4.57 \mathrm{c}-\mathrm{e}$ & $4.59 \mathrm{~b}$ & 0.4 \\
Tom-175 & $4.53 \mathrm{c}-\mathrm{e}$ & $4.58 \mathrm{bc}$ & 1.1 \\
Susceptible mean & & & 0.8 \\
Commercial & & & -3.2 \\
Hazera F & $4.63 \mathrm{~b}-\mathrm{e}$ & $4.48 \mathrm{c}-\mathrm{h}$ & -4.0 \\
H-2274 & $4.66 \mathrm{~b}-\mathrm{e}$ & $4.44 \mathrm{e}-\mathrm{h}$ & -2.0 \\
Commercial & & & \\
mean & & & \\
Overall mean & 4.61 & 4.51 & -7 \\
\hline Diffent & & \\
\hline
\end{tabular}

Different letters in each column indicate significance $(P<0.05)$.

affect the assimilation of proteins in roots. Therefore, heat stress may decrease tomato fruit mineral quality, partly via effects on root nutrient relations.

3.5. Total Phenols Content (TPC) of Tomatoes. Under hightemperature stress, phenolic content significantly $(P<0.0001)$ increased by $38.16 \%$ in all tomatoes compared to the control. Phenolic compound increase rates were $35.17 \%, 47.72 \%$, and $58.45 \%$ in tolerant, susceptible genotypes, and commercial varieties. The highest increase in tolerant genotypes was $107.4 \%$ in Tom-108 genotype, followed by Tom-111 (73.01\%), Tom233 (70.57\%), Tom-26 (66.19\%), and Tom-116 (58.07\%) (Table 7 and Figure 3(e)). There was a $6.73 \%$ drop in the Tom201B genotype compared to the control. The total phenolic content increase in susceptible genotypes was $58.07 \%$ in Tom116 and $37.36 \%$ in Tom-175. An increase in phenol content was found in all tomatoes except the Tom-201B genotype under high-temperature stress. While $\mathrm{H}-2274$ from commercial varieties increased phenols by $85.17 \%$, this increase was $31.52 \%$ in the Hazera56 $F_{1}$ variety (Table 7 ). It was reported that the total phenol content in tomato genotypes increased under high-temperature stress [41]. Phenolic compounds are important antioxidants produced by plants under stress as a
TABLE 6: EC values of tomato fruits grown in control and hightemperature stress $\left(\mathrm{dSm}^{-1}\right)$.

\begin{tabular}{|c|c|c|c|}
\hline Tolerant & Control & $\begin{array}{c}\text { High } \\
\text { temperature }\end{array}$ & $\begin{array}{c}\text { Relative change } \\
\text { (\%) }\end{array}$ \\
\hline Tom-12 & $5.26 \mathrm{f}-\mathrm{h}$ & $5.48 \mathrm{a}-\mathrm{c}$ & 4.2 \\
\hline Tom-14 & $4.83 \mathrm{hi}$ & $5.46 \mathrm{a}-\mathrm{c}$ & 13.0 \\
\hline Tom-19 & $6.33 \mathrm{a}$ & $5.43 \mathrm{a}-\mathrm{c}$ & -14.2 \\
\hline Tom-20 & $5.80 \mathrm{~b}-\mathrm{e}$ & $4.93 \mathrm{c}$ & -15.0 \\
\hline Tom-26 & $6.15 \mathrm{a}-\mathrm{d}$ & $5.40 \mathrm{a}-\mathrm{c}$ & -12.2 \\
\hline Tom-40 & $6.34 \mathrm{a}$ & $5.59 \mathrm{a}-\mathrm{c}$ & -11.8 \\
\hline Tom-47 & $5.43 \mathrm{e}-\mathrm{g}$ & $6.13 \mathrm{a}$ & 12.9 \\
\hline Tom-108 & $5.63 \mathrm{ef}$ & $5.40 a-c$ & -4.1 \\
\hline Tom-111 & $6.29 \mathrm{a}-\mathrm{c}$ & $4.86 \mathrm{c}$ & -22.7 \\
\hline Tom-114 & $5.79 \mathrm{c}-\mathrm{e}$ & $5.59 \mathrm{a}-\mathrm{c}$ & -3.5 \\
\hline Tom-115 & $4.39 \mathrm{i}$ & $5.06 \mathrm{bc}$ & 15.3 \\
\hline Tom-119 & $6.32 \mathrm{ab}$ & $5.00 \mathrm{c}$ & -20.9 \\
\hline Tom-165 & $5.19 \mathrm{f}-\mathrm{h}$ & $5.41 \mathrm{a}-\mathrm{c}$ & 4.2 \\
\hline Tom-173 & $6.28 \mathrm{a}-\mathrm{c}$ & $5.90 \mathrm{ab}$ & -6.1 \\
\hline Tom-201-B & $5.31 \mathrm{e}-\mathrm{h}$ & $5.93 \mathrm{ab}$ & 11.7 \\
\hline Tom-211 & $5.03 \mathrm{gh}$ & $5.17 \mathrm{bc}$ & 2.8 \\
\hline Tom-225 & $5.24 \mathrm{f}-\mathrm{h}$ & $5.56 \mathrm{a}-\mathrm{c}$ & 6.1 \\
\hline Tom-230 & $5.33 \mathrm{e}-\mathrm{h}$ & $5.60 \mathrm{a}-\mathrm{c}$ & 5.1 \\
\hline Tom-232 & $5.43 \mathrm{e}-\mathrm{g}$ & $5.39 \mathrm{a}-\mathrm{c}$ & -0.7 \\
\hline Tom-233 & $5.31 \mathrm{e}-\mathrm{h}$ & $5.18 \mathrm{bc}$ & -2.5 \\
\hline Tolerant mean & & & -1.9 \\
\hline \multicolumn{4}{|l|}{ Susceptible } \\
\hline Tom-116 & $5.21 \mathrm{f}-\mathrm{g}$ & $5.12 \mathrm{bc}$ & -1.7 \\
\hline Tom-175 & $5.67 \mathrm{~d}-\mathrm{f}$ & $5.20 \mathrm{bc}$ & -8.3 \\
\hline Susceptible mean & & & -5.0 \\
\hline \multicolumn{4}{|l|}{ Commercial } \\
\hline Hazera $F_{1}$ & $6.29 \mathrm{a}-\mathrm{c}$ & $5.53 \mathrm{a}-\mathrm{c}$ & -12.1 \\
\hline $\mathrm{H}-2274$ & $6.43 \mathrm{a}$ & $5.72 \mathrm{a}-\mathrm{c}$ & -11.0 \\
\hline Commercial & & & -11.6 \\
\hline Overall mean & 5.64 & 5.42 & -3.0 \\
\hline
\end{tabular}

Different letters in each column indicate significance $(P<0.05)$.

defense mechanism. While increasing phenolic substances help tomato plants resist stress under high-temperature stress, it benefits as an antioxidant to people who consume the fruit [3]. Rivero et al. [47] reported that once the temperature was increased from $25^{\circ} \mathrm{C}$ to $35^{\circ} \mathrm{C}$, the total phenol content of tomato plants increased by $144 \%$ compared to the control. In the same study, at high-temperature stress, while there was an increase in phenolic substances, flavones, one of the antioxidants, decreased by an average of $19.6 \%$ compared to the control. ROS (Reactive Oxygen Species) damage occurs in plants in hightemperature stress. To control ROS, plant tissues contain antioxidative enzymes scavenging ROS such as superoxide dismutase, ascorbate peroxidase, catalase, glutathione reductase, and nonenzymatic antioxidants such as ascorbate, glutathione, phenolic compounds, and tocopherols. [48]. Phenolics are significant secondary metabolites that defense against oxidative stress with ROS as well as against lipid peroxidation, protein denaturation, and DNA damage [49]. This study showed that phenolics increased in tomato fruit under high-temperature stress and exhibited antioxidant properties. While this is a defense tool against stress for tomato plants, it is also an important antioxidant source for people who consume the heat-tolerant tomato genotypes' fruits. 
TABLE 7: Total phenolic content (TPC) of tomato fruits grown under control and high-temperature stress (mg GAE/100 g FW).

\begin{tabular}{|c|c|c|c|}
\hline Tolerant & Control & $\begin{array}{c}\text { High } \\
\text { temperature }\end{array}$ & $\begin{array}{c}\text { Relative change } \\
\text { (\%) }\end{array}$ \\
\hline Tom-12 & $\begin{array}{c}493.87 \\
\mathrm{~b}-\mathrm{g}\end{array}$ & $812.22 \mathrm{a}-\mathrm{c}$ & 64.5 \\
\hline Tom-14 & $\begin{array}{c}588.08 \\
a-g\end{array}$ & $847.06 \mathrm{a}$ & 44.0 \\
\hline Tom-19 & $\begin{array}{c}670.25 \\
a-b\end{array}$ & $836.89 \mathrm{ab}$ & 24.9 \\
\hline Tom-20 & $\begin{array}{c}668.84 \\
a-b\end{array}$ & $736.00 \mathrm{a}-\mathrm{d}$ & 10.0 \\
\hline Tom-26 & $\begin{array}{c}448.54 \\
\mathrm{e}-\mathrm{g}\end{array}$ & $745.44 \mathrm{a}-\mathrm{d}$ & 66.2 \\
\hline Tom-40 & $\begin{array}{c}519.04 \\
\mathrm{~b}-\mathrm{g}\end{array}$ & $786.86 \mathrm{a}-\mathrm{c}$ & 51.6 \\
\hline Tom-47 & $\begin{array}{c}494.54 \\
\text { b-g }\end{array}$ & $603.00 \mathrm{~d}-\mathrm{e}$ & 21.9 \\
\hline Tom-108 & $412.14 \mathrm{~g}$ & $853.29 \mathrm{a}$ & 107.0 \\
\hline Tom-111 & $\begin{array}{c}482.49 \\
\mathrm{c}-\mathrm{g}\end{array}$ & $834.78 \mathrm{a}-\mathrm{b}$ & 73.0 \\
\hline Tom-114 & $624.61 \mathrm{a}-\mathrm{f}$ & $783.46 \mathrm{a}-\mathrm{c}$ & 25.4 \\
\hline Tom-115 & $609.51 \mathrm{a}-\mathrm{f}$ & $670.95 \mathrm{~b}-\mathrm{e}$ & 10.1 \\
\hline Tom-119 & $\begin{array}{c}625.78 \\
a-e\end{array}$ & $851.53 \mathrm{a}$ & 36.1 \\
\hline Tom-165 & $744.83 \mathrm{a}$ & $813.75 \mathrm{a}-\mathrm{c}$ & 9.3 \\
\hline Tom-173 & $\begin{array}{c}488.60 \\
\mathrm{~b}-\mathrm{g}\end{array}$ & $650.19 \mathrm{c}-\mathrm{e}$ & 33.1 \\
\hline Tom-201-B & $\begin{array}{l}595.70 \\
\mathrm{a}-\mathrm{g}\end{array}$ & $555.35 \mathrm{e}$ & -6.8 \\
\hline Tom-211 & $\begin{array}{c}663.29 \\
a-c\end{array}$ & $753.78 \mathrm{a}-\mathrm{d}$ & 13.6 \\
\hline Tom-225 & $609.64 \mathrm{a}-\mathrm{f}$ & $693.57 \mathrm{a}-\mathrm{e}$ & 13.8 \\
\hline Tom-230 & $\begin{array}{c}647.99 \\
a-d\end{array}$ & $757.50 \mathrm{a}-\mathrm{d}$ & 16.9 \\
\hline Tom-232 & $\begin{array}{c}645.68 \\
a-d\end{array}$ & $763.78 \mathrm{a}-\mathrm{d}$ & 18.3 \\
\hline Tom-233 & $\begin{array}{c}477.47 \\
\mathrm{~d}-\mathrm{g}\end{array}$ & $814.43 \mathrm{a}-\mathrm{c}$ & 70.6 \\
\hline $\begin{array}{l}\text { Tolerant mean } \\
\text { Susceptible }\end{array}$ & & & 35.2 \\
\hline Tom-116 & $\begin{array}{c}525.94 \\
\mathrm{~b}-\mathrm{g}\end{array}$ & $831.37 \mathrm{a}-\mathrm{b}$ & 58.1 \\
\hline Tom-175 & $\begin{array}{c}440.23 \\
\mathrm{f}-\mathrm{g}\end{array}$ & $604.68 \mathrm{~d}-\mathrm{e}$ & 37.4 \\
\hline $\begin{array}{l}\text { Susceptible } \\
\text { mean } \\
\text { Commercial }\end{array}$ & & & 47.7 \\
\hline Hazera $\mathrm{F}_{1}$ & $598.21 \mathrm{a}-\mathrm{f}$ & $786.79 \mathrm{a}-\mathrm{c}$ & 31.5 \\
\hline H-2274 & $\begin{array}{c}450.99 \\
\text { e-g }\end{array}$ & $835.98 \mathrm{a}-\mathrm{b}$ & 85.4 \\
\hline $\begin{array}{l}\text { Commercial } \\
\text { mean }\end{array}$ & & & 58.5 \\
\hline Overall mean & 563.59 & 759.28 & 38.2 \\
\hline
\end{tabular}

Different letters in each column indicate significant $(P<0.05),{ }^{*}$ : $\mathrm{GAE}=$ gallic acid equivalent, FW: fresh weight.

3.6. Total Flavonoid Content of Tomatoes. The flavonoids are decreased in tomato fruits under high-temperature stress. The variable was compared using the paired $t$-test, and the decrease of total flavonoids was found significant (Figure 3(f)). In general, an average of $19.60 \%$ drop was found in all tomatoes. The mean values of flavonoid decrease in tolerant and susceptible genotypes and commercial cultivars were $18.94 \%, 10.08 \%$, and $35.7 \%$, respectively (Table 8). However, the highest flavonoid increase was in Tom- 40 , one of the tolerant genotypes, with a rate of $21.46 \%$, followed by Tom-233 with $11.4 \%$. The highest flavonoid decrease was $57.89 \%$ in commercial variety $\mathrm{H}-2274$. There was a $41.54 \%$ decrease in the Tom-20 genotype (Table 8 , Figure 3(f)). Lokesha et al. [41] acknowledge that total flavonoid content increased in tomato genotypes under high-temperature stress compared to control. Flavonoids act as scavengers of various oxidizing species, i.e., superoxide, hydroxyl, and singlet radicals. This study determined that flavonoids remained at lower levels than control tomatoes under high-temperature stress, except Tom-40 and Tom233. As with phenols, no significant increases were found under high temperatures.

3.7. Vitamin C Content of Tomatoes. Since phenolic substances are reported to have a protective effect on ascorbic acid content [49], the presence of phenolics and flavonoids in tomato fruits can contribute to the preservation of vitamin $\mathrm{C}$ levels [50]. Vitamin $C$ content of tomato genotypes significantly $(P<0.0422)$ increased (Figure $3(\mathrm{~g}))$, and an average of increase was $3.54 \%$ in all tomatoes under high-temperature stress. Average vitamin $\mathrm{C}$ increase rates in tolerant and susceptible genotypes and commercial cultivars were 3.15\%, $6.40 \%$, and $4.60 \%$, respectively. The highest increase in vitamin C was determined as $17.3 \%$ in the tolerant Tom- 47 genotype. There were also increases in Tom-40 (16.6\%), Tom233 (14.9\%), Tom-108 (12.8\%), Tom-225 (12.2\%), and Tom-12 (11.4\%) genotypes (Table 9). A 36.7\% decrease in vitamin C was found in the Tom-119 genotype (Figure $3(\mathrm{~g})$ ). Among the commercial varieties, Hazera $\mathrm{F}_{1}$ showed an increase of $13.3 \%$, while the variety $\mathrm{H}-2274$ presented a decrease of $4.1 \%$. Tom47, Tom-40, and Tom-233 genotypes provided more vitamin $\mathrm{C}$ increase than commercial varieties (Table 9). Akhoundnejad [51] reported that high-temperature stress caused a change in the vitamin $\mathrm{C}$ content of tomato genotypes, and while it increased the vitamin $\mathrm{C}$ content of some genotypes, some genotypes determined a decrease in the vitamin $\mathrm{C}$ content. Hernández et al. [52] stated that the application of temperature stress during flowering and fruit set stages increased the vitamin $\mathrm{C}$ content, and there may be a relationship between the increasing of vitamin $\mathrm{C}$ and the adaptation of plant metabolism to high-temperature stress. In another study of high-temperature stress in tomato genotypes, there was no significant difference in vitamin $\mathrm{C}$ content between susceptible genotypes under stress conditions compared to the control, but the vitamin $\mathrm{C}$ content was higher in all tolerant genotypes [41].

3.8. Lycopene Content of Tomatoes. In this study, general decreases in the content of tomato lycopene were found under high-temperature stress (Figure 3(h)). There was an average decline of $3.86 \%$ in all tomatoes. However, there were also lycopene-increasing genotypes. The highest increase was in the Tom-12 genotype with 7.27\%. An increase in lycopene 
TABLE 8: Total flavonoids of tomato fruits grown under control and high temperature (mg Rutin eq/100 g FW).

\begin{tabular}{|c|c|c|c|}
\hline Tolerant & Control & $\begin{array}{c}\text { High } \\
\text { temperature }\end{array}$ & $\begin{array}{c}\text { Relative change } \\
(\%)\end{array}$ \\
\hline Tom-12 & $35.2 \mathrm{ab}$ & $21.6 \mathrm{c}-\mathrm{e}$ & -38.6 \\
\hline Tom-14 & $30.2 \mathrm{~b}-\mathrm{e}$ & $24.7 \mathrm{~b}-\mathrm{d}$ & -18.2 \\
\hline Tom-19 & $26.8 c-e$ & $20.5 \mathrm{de}$ & -23.5 \\
\hline Tom-20 & $33.7 \mathrm{a}-\mathrm{d}$ & $19.7 \mathrm{de}$ & -41.5 \\
\hline Tom-26 & $29.8 \mathrm{~b}-\mathrm{e}$ & $28.7 \mathrm{a}-\mathrm{c}$ & -3.7 \\
\hline Tom-40 & $24.7 \mathrm{e}$ & $30.0 \mathrm{ab}$ & 21.5 \\
\hline Tom-47 & $27.3 \mathrm{~b}-\mathrm{e}$ & $18.6 \mathrm{de}$ & -31.9 \\
\hline Tom-108 & $27.1 \mathrm{~b}-\mathrm{e}$ & $23.4 \mathrm{~b}-\mathrm{e}$ & -13.7 \\
\hline Tom-111 & $30.8 \mathrm{~b}-\mathrm{e}$ & $20.5 \mathrm{de}$ & -33.4 \\
\hline Tom-114 & $29.8 \mathrm{~b}-\mathrm{e}$ & $22.5 \mathrm{~b}-\mathrm{e}$ & -24.5 \\
\hline Tom-115 & $32.5 \mathrm{a}-\mathrm{e}$ & $25.9 \mathrm{~b}-\mathrm{d}$ & -20.3 \\
\hline Tom-119 & $28.6 \mathrm{~b}-\mathrm{e}$ & $25.7 \mathrm{~b}-\mathrm{d}$ & -10.1 \\
\hline Tom-165 & $30.0 \mathrm{~b}-\mathrm{e}$ & $21.0 \mathrm{c}-\mathrm{e}$ & -30.0 \\
\hline Tom-173 & $29.3 \mathrm{~b}-\mathrm{e}$ & $24.1 \mathrm{~b}-\mathrm{e}$ & -17.8 \\
\hline Tom-201-B & $28.1 \mathrm{~b}-\mathrm{e}$ & $20.1 \mathrm{de}$ & -28.5 \\
\hline Tom-211 & $26.8 c-e$ & $23.1 \mathrm{~b}-\mathrm{e}$ & -13.8 \\
\hline Tom-225 & $30.1 \mathrm{~b}-\mathrm{e}$ & $24.4 \mathrm{~b}-\mathrm{e}$ & -18.9 \\
\hline Tom-230 & $28.5 \mathrm{~b}-\mathrm{e}$ & $23.3 \mathrm{~b}-\mathrm{e}$ & -18.3 \\
\hline Tom-232 & $26.0 \mathrm{de}$ & $19.5 \mathrm{de}$ & -25.0 \\
\hline Tom-233 & $30.7 \mathrm{~b}-\mathrm{e}$ & $34.2 \mathrm{a}$ & 11.4 \\
\hline Tolerant mean & & & -18.9 \\
\hline \multicolumn{4}{|l|}{ Susceptible } \\
\hline Tom-116 & $31.9 \mathrm{a}-\mathrm{e}$ & $23.2 \mathrm{~b}-\mathrm{e}$ & -27.3 \\
\hline Tom-175 & $28.1 \mathrm{~b}-\mathrm{e}$ & $30.1 \mathrm{ab}$ & 7.1 \\
\hline Susceptible mean & & & -10.1 \\
\hline \multicolumn{4}{|l|}{ Commercial } \\
\hline Hazera $F_{1}$ & $34.8 \mathrm{a}-\mathrm{c}$ & $30.1 \mathrm{ab}$ & -13.5 \\
\hline H-2274 & 39.9 a & $16.8 \mathrm{e}$ & -57.9 \\
\hline $\begin{array}{l}\text { Commercial } \\
\text { mean }\end{array}$ & & & -35.7 \\
\hline Overall mean & 30.0 & 23.82 & -19.6 \\
\hline
\end{tabular}

Different letters in each column indicate significance $(P<0.05)$, FW: fresh weight.

under stress was also noted in the Tom-26 (4.40\%), Tom-20 (1.72\%), and Tom-19 (1.46\%) genotypes. The lycopene content of the Hazera56 $\mathrm{F}_{1}$ commercial variety decreased by $6.24 \%$, while the amount of $\mathrm{H}-2274$ increased by $3.64 \%$. The highest lycopene decrease was $33.98 \%$ in the Tom-230 genotype (Table 10, Figure 3(h)). Sharma and Le Maguer [53] reported that 72 to $92 \%$ of lycopene in tomato fruit is associated with peel as the water-insoluble fraction. Likewise, high-temperature stress in tomatoes affects the lycopene content, and the carotenoids and lycopene content in the plastids increase as the fruits mature [45]. It is reported that fruit temperature and irradiance affected final fruit composition [18] and increasing the temperature from 21 to $26^{\circ} \mathrm{C}$ was noted to lower the total carotene content without affecting the lycopene content. Moreover, an increase in temperature from $27^{\circ} \mathrm{C}$ to $32^{\circ} \mathrm{C}$ decreases ascorbate, lycopene, and antecedent content while it increases rutin, caffeic acid derivatives, and glucoside contents [18]. Karipcin et al. [54] reported that lycopene was higher in high-temperature tolerant local tomato lines selected in the semidrought region than common-commercial hybrid varieties. It has been reported in another study [41] that the carotenoid and lycopene content of tomato is higher in the control treatment than in
TABLE 9: Vitamin C of tomato fruits grown in control and hightemperature stress $(\mathrm{mg} / 100 \mathrm{~g} \mathrm{FW})$.

\begin{tabular}{lccc}
\hline Tolerant & Control & $\begin{array}{c}\text { High } \\
\text { temperature }\end{array}$ & $\begin{array}{c}\text { Relative change } \\
(\%)\end{array}$ \\
\hline Tom-12 & $17.21 \mathrm{j}$ & $19.50 \mathrm{~h}-\mathrm{k}$ & 11.4 \\
Tom-14 & $20.95 \mathrm{~d}$ & $22.55 \mathrm{~b}-\mathrm{e}$ & 6.7 \\
Tom-19 & $22.28 \mathrm{bc}$ & $23.55 \mathrm{a}-\mathrm{c}$ & 4.5 \\
Tom-20 & $16.99 \mathrm{j}$ & $15.96 \mathrm{~m}$ & -6.9 \\
Tom-26 & $18.39 \mathrm{i}$ & $16.29 \mathrm{~m}$ & -14.3 \\
Tom-40 & $17.50 \mathrm{j}$ & $21.05 \mathrm{~d}-\mathrm{i}$ & 16.6 \\
Tom-47 & $18.65 \mathrm{~g}-\mathrm{i}$ & $22.68 \mathrm{~b}-\mathrm{d}$ & 17.3 \\
Tom-108 & $20.82 \mathrm{~d}$ & $24.20 \mathrm{ab}$ & 12.8 \\
Tom-111 & $16.32 \mathrm{k}$ & $17.04 \mathrm{~lm}$ & 3.4 \\
Tom-114 & $21.18 \mathrm{~d}$ & $20.34 \mathrm{f}-\mathrm{j}$ & -4.6 \\
Tom-115 & $19.02 \mathrm{fg}$ & $21.12 \mathrm{~d}-\mathrm{i}$ & 9.3 \\
Tom-119 & $23.81 \mathrm{a}$ & $17.50 \mathrm{k}-\mathrm{m}$ & -36.7 \\
Tom-165 & $18.88 \mathrm{f}-\mathrm{i}$ & $21.78 \mathrm{c}-\mathrm{g}$ & 13.2 \\
Tom-173 & $23.30 \mathrm{a}$ & $21.63 \mathrm{c}-\mathrm{h}$ & -8.4 \\
Tom-201-B & 18.95 & $19.95 \mathrm{~g}-\mathrm{j}$ & 4.2 \\
Tom-211 & $\mathrm{f}-\mathrm{h}$ & $22.84 \mathrm{~b}-\mathrm{d}$ & -0.3 \\
Tom-225 & $22.70 \mathrm{~b}$ & $25.19 \mathrm{a}$ & 12.2 \\
Tom-230 & $21.89 \mathrm{c}$ & $22.15 \mathrm{~b}-\mathrm{f}$ & 4.8 \\
Tom-232 & $19.64 \mathrm{~d} \mathrm{e}$ & $20.36 \mathrm{e}-\mathrm{j}$ & 2.9 \\
Tom-233 & $18.73 \mathrm{~g}-\mathrm{i}$ & $22.14 \mathrm{~b}-\mathrm{g}$ & 14.9 \\
Tolerant mean & & & 3.2 \\
Susceptible & & & \\
Tom-116 & $17.07 \mathrm{j}$ & $19.38 \mathrm{i}-\mathrm{k}$ & 11.6 \\
Tom-175 & $18.43 \mathrm{hi}$ & $18.70 \mathrm{j}-\mathrm{l}$ & 1.2 \\
Susceptible mean & & & 6.4 \\
Commercial & & & \\
Hazera F & $21.90 \mathrm{c}$ & $25.44 \mathrm{a}$ & -4.1 \\
H-2274 & $19.40 \mathrm{ef}$ & $18.68 \mathrm{j}-\mathrm{l}$ & 3.6 \\
Commercial & & & \\
mean & & & \\
Overall mean & 19.79 & 20.83 & \\
\hline Dffent & \\
\hline
\end{tabular}

Different letters in each column indicate significance $(P<0.05)$, FW: fresh weight.

the high-temperature application. Additionally, there is less carotenoid and lycopene content accumulation in susceptible genotypes than the tolerant genotypes under both control and stress conditions. Likewise, temperature significantly affects total carotenoids and lycopene content [41]. The temperature in the fruit ripening period plays an essential role in the biosynthesis of lycopene compared to the physical growth period of the fruit. The high-temperature stress was reported to cause lycopene degradation [55] and decrease [56] and inhibition [20] biosynthesis. Shi and Maguer [57] reported that relatively high temperatures $\left(38^{\circ} \mathrm{C}\right)$ inhibited lycopene production while low temperatures inhibited both fruit ripening and lycopene production.

3.9. Beta-Carotene of Tomatoes. The high-temperature stress significantly $(P<0.0095)$ decreased $\beta$-carotene pigment of tomato genotypes (Figure 3(i)). At high-temperature stress, $\beta$-carotene pigment decreased by an average of $4.64 \%$ in all tomatoes. However, among the high-temperature tolerant tomato genotypes, increases were found in the content of betacarotene in Tom-12 (7.78\%), Tom-20 (6.45\%), and Tom-19 
TABLE 10: Lycopene content of tomato fruits grown in control and high temperatures (mg/100 g FW).

\begin{tabular}{|c|c|c|c|}
\hline Tolerant & Control & High temperature & Relative change (\%) \\
\hline Tom-12 & $61.29 c-g$ & $65.74 \mathrm{a}$ & 7.3 \\
\hline Tom-14 & $60.51 \mathrm{~d}-\mathrm{i}$ & $59.54 \mathrm{a}$ & -1.6 \\
\hline Tom-19 & $60.03 \mathrm{e}-\mathrm{i}$ & $60.91 \mathrm{a}$ & 1.5 \\
\hline Tom-20 & $60.11 \mathrm{~d}-\mathrm{i}$ & $61.15 \mathrm{a}$ & 1.7 \\
\hline Tom-26 & $61.03 \mathrm{~d}-\mathrm{i}$ & $63.71 \mathrm{a}$ & 4.4 \\
\hline Tom-40 & $61.13 \mathrm{~d}-\mathrm{h}$ & $58.98 \mathrm{a}$ & -3.5 \\
\hline Tom-47 & $59.24 \mathrm{~g}-\mathrm{i}$ & $58.18 \mathrm{a}$ & -1.8 \\
\hline Tom-108 & $61.66 \mathrm{~b}-\mathrm{f}$ & $58.62 \mathrm{a}$ & -4.9 \\
\hline Tom-111 & $66.74 \mathrm{a}$ & $59.38 \mathrm{a}$ & -11.0 \\
\hline Tom-114 & $63.75 \mathrm{~b}$ & $58.98 \mathrm{a}$ & -7.5 \\
\hline Tom-115 & $61.82 \mathrm{~b}-\mathrm{f}$ & $58.98 \mathrm{a}$ & -4.6 \\
\hline Tom-119 & $59.85 \mathrm{f}-\mathrm{i}$ & $58.16 \mathrm{a}$ & -2.8 \\
\hline Tom-165 & $60.11 \mathrm{~d}-\mathrm{i}$ & $58.20 \mathrm{a}$ & -3.2 \\
\hline Tom-173 & $58.92 \mathrm{i}$ & $58.11 \mathrm{a}$ & -1.4 \\
\hline Tom-201-B & $62.22 \mathrm{~b}-\mathrm{d}$ & $58.28 \mathrm{a}$ & -6.3 \\
\hline Tom-211 & $59.06 \mathrm{hi}$ & $58.09 \mathrm{a}$ & -1.7 \\
\hline Tom-225 & $60.81 \mathrm{~d}-\mathrm{i}$ & $58.12 \mathrm{a}$ & -4.4 \\
\hline Tom-230 & $59.85 \mathrm{f}-\mathrm{i}$ & $39.52 \mathrm{~b}$ & -34.0 \\
\hline Tom-232 & $62.22 \mathrm{~b}-\mathrm{d}$ & $58.24 \mathrm{a}$ & -6.4 \\
\hline Tom-233 & $63.25 \mathrm{bc}$ & $58.38 \mathrm{a}$ & -7.7 \\
\hline Tolerant mean & & & -4.4 \\
\hline \multicolumn{4}{|l|}{ Susceptible } \\
\hline Tom-116 & $59.01 \mathrm{i}$ & $58.14 \mathrm{a}$ & -1.4 \\
\hline Tom-175 & $60.59 \mathrm{~d}-\mathrm{i}$ & $58.88 \mathrm{a}$ & -2.8 \\
\hline Susceptible mean & & & -2.1 \\
\hline \multicolumn{4}{|l|}{ Commercial } \\
\hline Hazera $\mathrm{F}_{1}$ & $60.10 \mathrm{~b}-\mathrm{e}$ & $58.20 \mathrm{a}$ & -6.2 \\
\hline $\mathrm{H}-2274$ & $61.09 \mathrm{~d}-\mathrm{h}$ & $63.31 \mathrm{a}$ & 3.6 \\
\hline Commercial mean & & & -1.3 \\
\hline Overall mean & 61.02 & 58.66 & -3.9 \\
\hline
\end{tabular}

Different letters in each column indicate significance $(P<0.05)$, FW: fresh weight.

(2.04\%) genotypes. Also, a decrease of $3.25 \%$ was noted in susceptible genotypes, while a decrease of $3.88 \%$ in Hazera $F_{1}$ and an increase of $10.31 \%$ in beta-carotene in $\mathrm{H}-2274$ were determined (Table 11). The most $\beta$-carotene pigment decrease was shown in Tom-230. (Figure 3(i)). Gautier et al. [18] stated that $\beta$-carotene loss increased with the increase in the temperature from $27^{\circ} \mathrm{C}$ to $32^{\circ} \mathrm{C}$. Similarly, Karipcin et al. [54] reported that $\beta$-carotene content in high-temperature tolerant local tomato lines was higher than common-commercial hybrid cultivars.

3.10. Principal Component Analysis (PCA) of the Data. The principal component analysis (PCA) is a multivariate analysis method that represents identifying genotypes and scatters the genotypes by measuring traits as variables. In this study, the first two principal components plotted on the $x$ - and $y$-axis contributed 27.3 and $18.5 \%$ toward the total variance of tomato genotypes under control growth conditions (Figure 4(a)). Tom-111 disintegrated from the tomato genotypes with high lycopene, titratable acidity, and $\beta$-carotene content but clustered with Tom-40, Tom-114, Tom 201-B, and Tom-232 considering all of the variables regarding control conditions. The lycopene, titratable acidity TTS, $\mathrm{pH}$, and total flavonoid content were the most variable traits. Tom-173 separated from the genotypes with the highest $\mathrm{pH}$ values but the lowest lycopene and $\beta$-carotene content.
The results of principal component analysis discriminated against tomato genotypes toward high-temperature stress considering quality parameters. Principal component 1 and principal component 2 explain 32.0 and $22.8 \%$ of the total variance (Figure 4(b)). Tom-230 separated from the genotypes with the lowest lycopene and $\beta$-carotene content and Tom-47 disintegrated with the highest EC and titratable values. Lycopene and $\beta$-carotene content were highly correlated and clustered the same group in the dependent variables. Tom-233 separated from the genotypes with the highest $\mathrm{pH}$ and total flavonoid content (Figure 4(b)).

The $x$ - and $y$-axes were shown on principal component analysis plots PC1 and PC2 contributed 24.6 and $21.4 \%$ of the total variance considering a relative change of tomato genotypes between control and high-temperature stress (Figure 4(c)). Inconspicuous Tom-230 genotype in control growth conditions was strongly discriminated from the germplasm related to its differentiation of lycopene and $\beta$-carotene content under high-temperature stress. The heat map shows that the lycopene and $\beta$-carotene content in relation to quality parameters was very similar to both control and high-temperature stress. The principal component analysis may have been suggested as a useful multivariate selection technique to discriminate tomato germplasm toward high-temperature stress. Sivakumar et al. [58] indicated that the principal component analysis (PCA) technique can be used as a tool for the selection and 
TABLE 11: $\beta$-carotene content of tomato fruits grown in control and high temperatures (mg/100 g FW).

\begin{tabular}{|c|c|c|c|}
\hline Tolerant & Control & High temperature & Relative change (\%) \\
\hline Tom-12 & $0.642 \mathrm{c}-\mathrm{e}$ & $0.692 \mathrm{ab}$ & 7.8 \\
\hline Tom-14 & $0.672 a-c$ & $0.635 \mathrm{ab}$ & -5.5 \\
\hline Tom-19 & $0.667 \mathrm{a}-\mathrm{d}$ & $0.680 \mathrm{ab}$ & 2.0 \\
\hline Tom-20 & $0.655 \mathrm{~b}-\mathrm{e}$ & $0.697 \mathrm{ab}$ & 6.5 \\
\hline Tom-26 & $0.648 \mathrm{~b}-\mathrm{e}$ & $0.689 \mathrm{ab}$ & 6.4 \\
\hline Tom-40 & $0.681 \mathrm{ab}$ & $0.626 \mathrm{ab}$ & -8.1 \\
\hline Tom-47 & $0.640 \mathrm{c}-\mathrm{e}$ & $0.609 \mathrm{ab}$ & -4.8 \\
\hline Tom-108 & $0.649 \mathrm{~b}-\mathrm{e}$ & $0.613 \mathrm{ab}$ & -5.5 \\
\hline Tom-111 & $0.702 \mathrm{a}$ & $0.619 \mathrm{ab}$ & -11.8 \\
\hline Tom-114 & $0.680 \mathrm{ab}$ & $0.618 \mathrm{ab}$ & -9.2 \\
\hline Tom-115 & $0.672 a-c$ & $0.627 \mathrm{ab}$ & -6.8 \\
\hline Tom-119 & $0.661 \mathrm{~b}-\mathrm{e}$ & $0.609 \mathrm{~b}$ & -7.8 \\
\hline Tom-165 & $0.694 \mathrm{~b}-\mathrm{e}$ & $0.609 \mathrm{~b}$ & -7.7 \\
\hline Tom-173 & $0.628 \mathrm{e}$ & $0.609 \mathrm{~b}$ & -3.1 \\
\hline Tom-201-B & $0.651 \mathrm{~b}-\mathrm{e}$ & $0.609 \mathrm{ab}$ & -6.4 \\
\hline Tom-211 & $0.641 \mathrm{c}-\mathrm{e}$ & $0.610 \mathrm{ab}$ & -5.1 \\
\hline Tom-225 & $0.639 c-e$ & $0.606 \mathrm{~b}$ & -5.2 \\
\hline Tom-230 & $0.629 \mathrm{e}$ & $0.417 \mathrm{c}$ & -33.7 \\
\hline Tom-232 & $0.661 \mathrm{~b}-\mathrm{e}$ & $0.611 \mathrm{ab}$ & -7.6 \\
\hline Tom-233 & $0.647 \mathrm{~b}-\mathrm{e}$ & $0.609 \mathrm{~b}$ & -5.9 \\
\hline Tolerant mean & & & -5.6 \\
\hline \multicolumn{4}{|l|}{ Susceptible } \\
\hline Tom-116 & $0.637 \mathrm{de}$ & $0.607 \mathrm{~b}$ & -4.2 \\
\hline Tom-175 & $0.631 \mathrm{de}$ & $0.616 \mathrm{ab}$ & -2.3 \\
\hline Susceptible mean & & & -3.3 \\
\hline \multicolumn{4}{|l|}{ Commercial } \\
\hline Hazera $\mathrm{F}_{1}$ & $0.632 \mathrm{de}$ & $0.607 \mathrm{~b}$ & -3.9 \\
\hline $\mathrm{H}-2274$ & $0.663 \mathrm{~b}-\mathrm{e}$ & $0.731 \mathrm{a}$ & 10.3 \\
\hline Commercial mean & & & 3.2 \\
\hline Overall mean & 0.587 & 0.623 & -4.6 \\
\hline
\end{tabular}

Different letters in each column indicate significance $(P<0.05)$, FW: fresh weight.
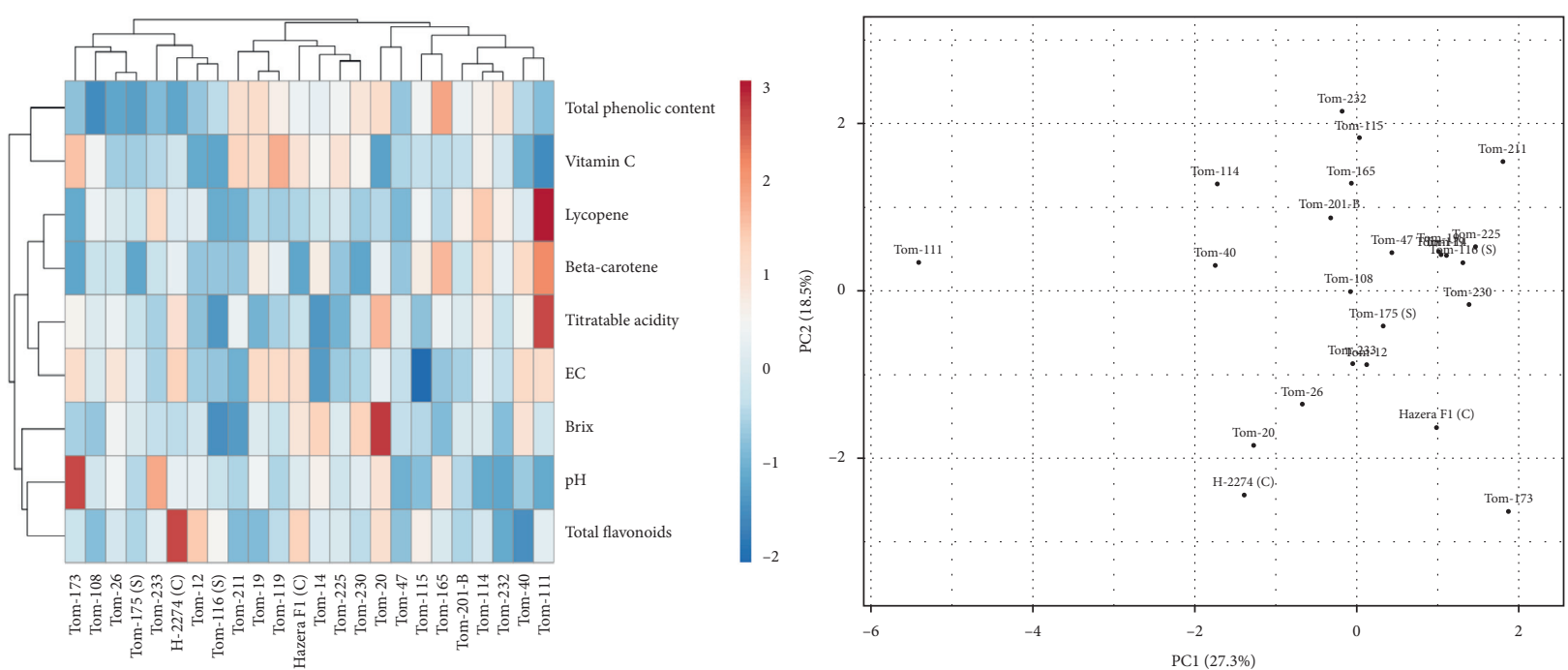

(a)

Figure 4: Continued. 

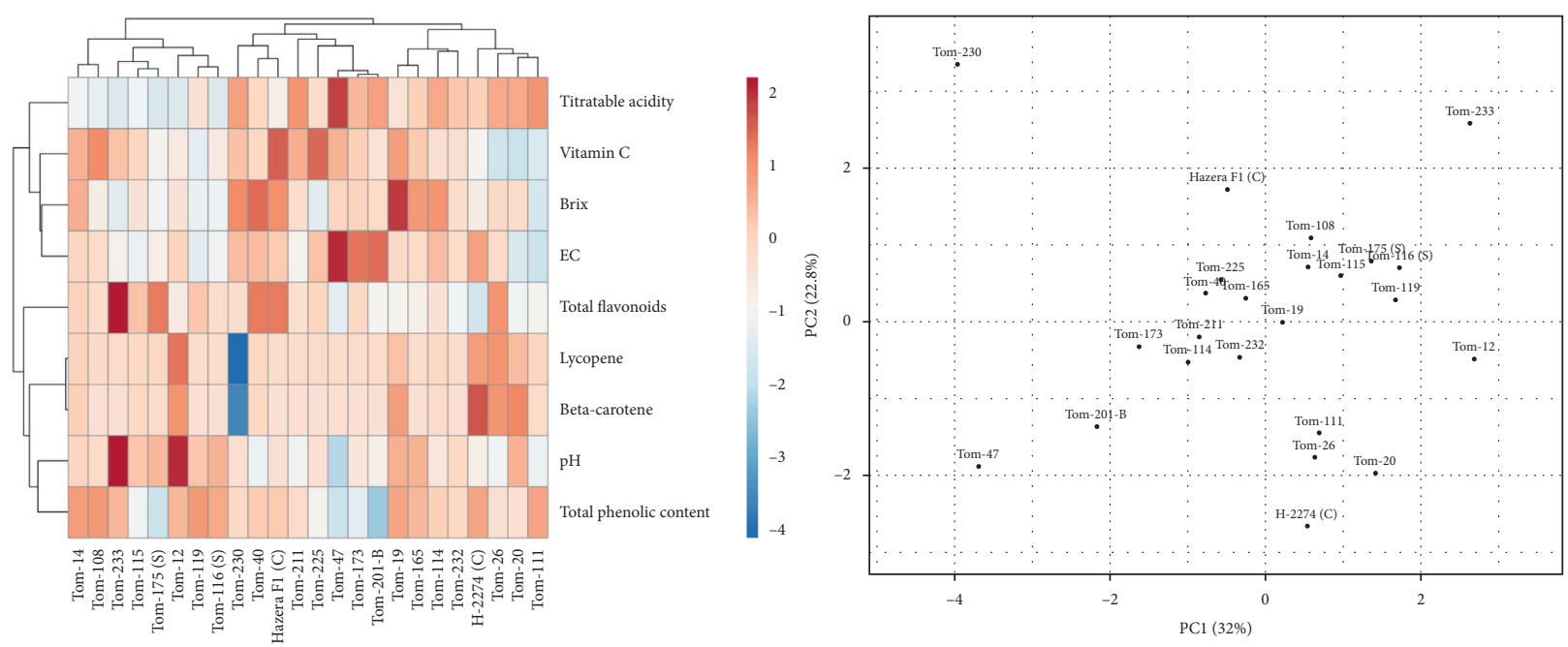

(b)
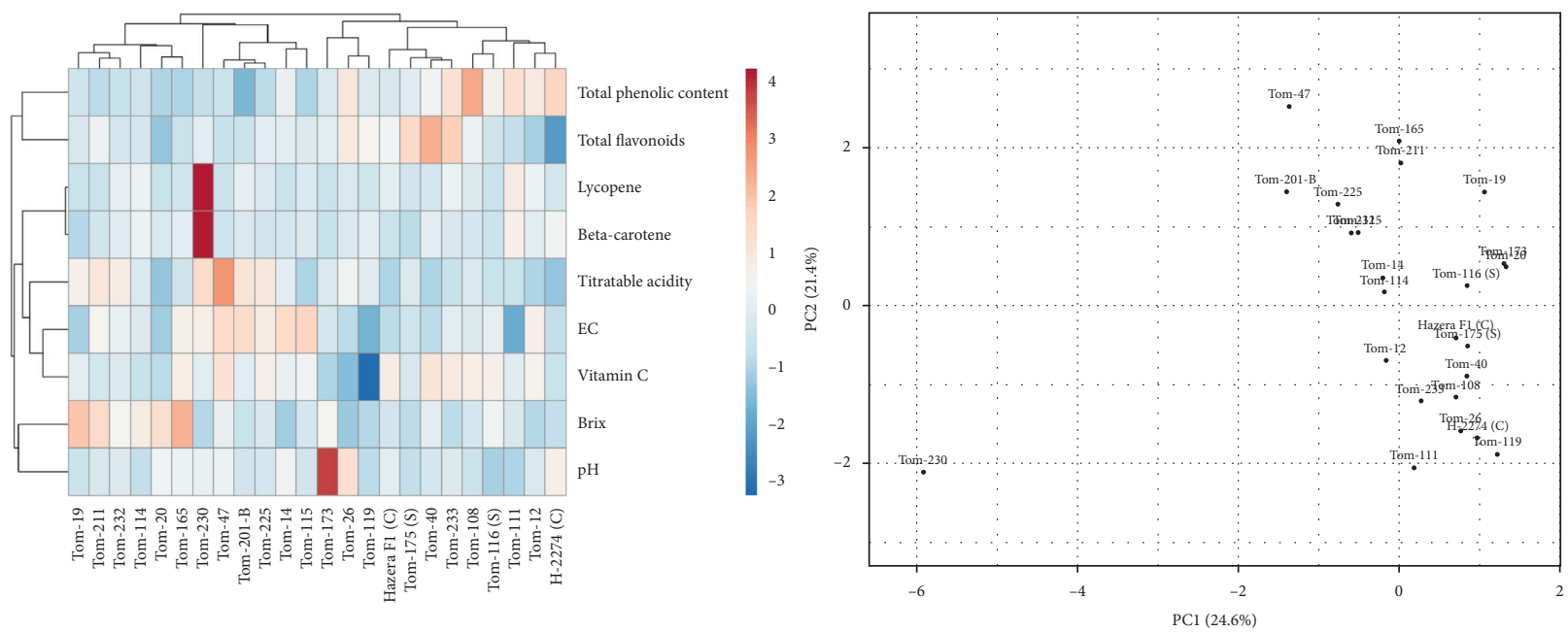

(c)

Figure 4: Heat map cluster (left) and principal component analysis (PCA) plot (right) of quality parameters profiles of control (a), high temperature (b), and relative change (c).

discrimination of tomato germplasm toward salt stress. Iqbal et al. [59] suggested multivariate analysis to assess the genetic divergence of tomatoes to select accessions in a breeding program.

\section{Conclusion}

It was revealed that twenty tolerant, two susceptible genotypes, and two commercial cultivars grown in high-temperature stress comparatively with the control had genotype differences in fruit nutrient contents. In tolerant tomato genotypes, in general, increases were found in total soluble solids, titratable acidity, total phenols, and vitamin $\mathrm{C}$ contents under hightemperature conditions, while decreases in $\mathrm{pH}, \mathrm{EC}$, total flavonoids, lycopene, and $\beta$-carotene were noted. However, different specific responses on the basis of genotypes and useful information for breeding studies have been identified. These data on fruit nutrient content and antioxidants will be helpful when breeding tomato varieties to be grown in high- temperature conditions. The world's agriculture is under threat of climate change. High-temperature tolerant tomato varieties may gain importance in the near future.

\section{Data Availability}

All the relevant data have been provided in the manuscript. The authors will provide additional details if required.

\section{Conflicts of Interest}

The authors declare that there are no conflicts of interest.

\section{Acknowledgments}

The authors wish to thank the Cukurova University Projects Office (BAP) for sponsoring the present investigation (FBA2016-5615). The authors also thank Prof. Dr. N. Ebru KAFKAS for providing the laboratory facilities. 


\section{References}

[1] D. Keeney, High Level Conferences on World Food Security: The Challenges of Climate Change and Bioenergy, FAO, Rome, Italy, 2008, http://www.fao.org/foodclimate/hlc-home/en/.

[2] Y. Akhoundnejad and H. Y. Dasgan, "Physiological performance of some high temperature tolerant tomato genotypes," International Journal of Scientific \& Technology Research, vol. 4, no. 7, pp. 57-74, 2018.

[3] S. Dere, Increasing the nutritional properties and quality of tomatoes with drought resistance, Ph.D. thesis, Cukurova University, Graduate School of Natural and Applied Sciences, Adana, Turkey, 2019.

[4] Y. Akhoundnejad and H. Y. Daşgan, "Photosynthesıs, transpiration, stomatal conductance of some melon (Cucumic melo L.) genotypes under different drought stress," Fresenius Environmental Bulletin, vol. 12, pp. 10974-10979, 2020.

[5] A. Acar, "Prepare for climate change," National Geograhic, pp. 84-87, 2010.

[6] R. García-Closas, A. Berenguer, M. J. Tormo et al., "Dietary sources of vitamin $\mathrm{C}$, vitamin $\mathrm{E}$ and specific carotenoids in Spain," British Journal of Nutrition, vol. 91, no. 6, pp. 10051011, 2004.

[7] M. Tomas, J. Beekwilder, R. D. Hall, O. Sagdic, D. Boyacioglu, and E. Capanoglu, "Industrial processing versus home processing of tomato sauce: effects on phenolics, flavonoids and in vitro bioaccessibility of antioxidants," Food Chemistry, vol. 220, pp. 51-58, 2017.

[8] H. Y. Daşgan and Y. Akhoundnejad, Determination of Tolerance Levels to High Temperature Stress of Different Local Tomato Genotypes, Examination of Their Morphological, Physiological and Agricultural Characteristics, Republic of Turkey Ministry of Agriculture and Forestry, Ankara, Turkey, 2013.

[9] E. A. Waraich, R. Ahmad, A. Halim, and T. Aziz, "Alleviation of temperature stress by nutrient management in crop plants: a review," Journal of Soil Science and Plant Nutrition, vol. 12, no. 2, pp. 221-244, 2012.

[10] S. S. Gill and N. Tuteja, "Reactive oxygen species and antioxidant machinery in abiotic stress tolerance in crop plants," Plant Physiology and Biochemistry, vol. 48, no. 12, pp. 909930, 2010.

[11] N. Suzuki, S. Koussevitzky, R. Mittler, and G. Miller, "ROS and redox signalling in the response of plants to abiotic stress," Plant, Cell \& Environment, vol. 35, no. 2, pp. 259-270, 2012.

[12] K. Vermeulen, K. Steppe, N. S. Liunh et al., "Simultaneous response of stem diameter, sap flow rate and leaf temperature of tomato plants to drought stress," Acta Horticulturae, vol. 801, pp. 1259-1266, 2007.

[13] J. Zhang, T. L. Li, and J. Xu, "Effects of sub-high temperature in daytime from different stages on tomato photosynthesis and yield in greenhouse," Transactions of the Chinese Society of Agricultural Engineering, vol. 24, no. 3, pp. 193-197, 2008.

[14] J. Zhang, J. Xiaodong, L. Tianlai, and Y. Zaiqiang, "Effect of moderately-high temperature stress on photosynthesis and carbohydrate in tomato (Lycopersico esculentum L.) leaves," African Journal of Agricultural Research, vol. 7, no. 3, pp. 487-492, 2012.

[15] A.-S. Mathieu, S. Lutts, B. Vandoorne et al., "High temperatures limit plant growth but hasten flowering in root chicory (Cichorium intybus) independently of vernalisation," Journal of Plant Physiology, vol. 171, no. 2, pp. 109-118, 2014.
[16] S. Curuk and K. Abak, "Adaptation of some tomato genotypes to humid and high temperature in Çukurova conditions, pollen viability and germination abilities," in Proceedings of the Turkey's Nation Horticulture Congress, pp. 1-6, Adana, Turkey, 1995.

[17] N. Çömlekçioğlu and M. K. Soylu, "Determination of high temperature tolerance via screening of flower and fruit formation in tomato," Yüzüncü Yıl University Journal of Agricultural Sciences (Turkey), vol. 20, no. 2, pp. 123-130, 2010.

[18] H. Gautier, V. Diakou-Verdin, C. Bénard et al., "How does tomato quality (sugar, acid, and nutritional quality) vary with ripening stage, temperature, and irradiance?" Journal of Agricultural and Food Chemistry, vol. 56, no. 4, pp. 1241-1250, 2008.

[19] N. Garg and D. S. Cheema, "Assessment of fruit quality attributes of tomato hybrids involving ripening mutants under high temperature conditions," Scientia Horticulturae, vol. 131, pp. 29-38, 2011.

[20] S. Guichard, N. Bertin, C. Leonardi, and C. Gary, "Tomato fruit quality in relation to water and carbon fluxes," Agronomie, vol. 21, no. 4, pp. 385-392, 2001.

[21] R. Zhou, X. Yu, K. H. Kjær, E. Rosenqvist, C.-O. Ottosen, and $\mathrm{Z}$. Wu, "Screening and validation of tomato genotypes under heat stress using $F_{v} / F_{m}$ to reveal the physiological mechanism of heat tolerance," Environmental and Experimental Botany, vol. 118, pp. 1-11, 2015.

[22] U. Singh, P. K. Patel, A. K. Singh et al., "Screening of tomato genotypes underhigh temperature stress for reproductive traits," Vegetable Science, vol. 42, no. 2, pp. 52-55, 2015.

[23] L. Spicher, J. Almeida, K. Gutbrod et al., "Essential role for phytol kinase and tocopherol in tolerance to combined light and temperature stress in tomato," Journal of Experimental Botany, vol. 68, no. 21-22, pp. 5845-5856, 2017.

[24] M. Alsamir, N. M. Ahmad, T. Mahmood, and R. Trethowan, "Morpho-physiological traits linked to high temperature stress tolerance in tomato (S. lycopersicum L.)," American Journal of Plant Sciences, vol. 08, no. 11, pp. 2681-2694, 2017.

[25] D. Poudyal, E. Rosenqvist, and C. O. Ottosen, "Phenotyping from lab to field-tomato lines screened for heat stress using $F_{v} / F_{m}$ maintain high fruit yield during thermal stress in the field," Functional Plant Biology, vol. 46, no. 1, pp. 44-55, 2018.

[26] H. Zhang, C. Pan, S. Gu et al., "Stomatal movements are involved in elevated $\mathrm{CO}_{2}$-mitigated high temperature stress in tomato," Physiologia Plantarum, vol. 165, no. 3, pp. 569-583, 2019.

[27] Y. Akhoundnejad, Y. H. Dasgan, and S. Karabiyik, "Pollen quality, pollen production and yield of some tomato (Solanum lycopersicum) genotypes under high temperature stress in eastern Mediterranean," Notulae Botanicae Horti Agrobotanici Cluj-Napoca, vol. 48, no. 2, pp. 893-905, 2020.

[28] S. N. Rajametov, E. Y. Yang, H. B. Jeong, M. C. Cho, S. Y. Chae, and N. Paudel, "Heat treatment in two tomato cultivars: a study of the effect on physiological and growth recovery," Horticulturae, vol. 7, no. 5, p. 119, 2021.

[29] A. Scarano, F. Olivieri, C. Gerardi et al., "Selection of tomato landraces with high fruit yield and nutritional quality under elevated temperatures," Journal of the Science of Food and Agriculture, vol. 100, no. 6, pp. 2791-2799, 2020.

[30] Y. Akhoundnejad, H. Y. Daşgan, G. Aydöner, A. Bol, and M. Ünlü, "Determination of field performance of some drought tolerant tomato genotypes," in Proceedings of the 9th National Vegetable Symposium, pp. 428-432, Konya, Turkey, 2012. 
[31] F. K. Sabir, S. Kusvuran, H. Y. Dasgan, and T. Agar, "Effects of 1-methylcyclopropene treatment on postharvest life and quality in four tomatoes cultivars," Journal of Animal and Plant Sciences, vol. 22, pp. 1086-1091, 2012.

[32] B. Bozan, Z. Tunalier, M. Kosar, A. Altıntas, and K. H. C. Baser, "Comparison of ascorbic and citric acid contents in emphasis type," in Proceedings of the 11th Symposium on Plant Origin, Ankara, Turkey, 1997.

[33] G. A. Spanos and R. E. Wrolstad, "Influence of processing and storage on the phenolic composition of thompson seedless grape juice," Journal of Agricultural and Food Chemistry, vol. 38, no. 7, pp. 1565-1571, 1990.

[34] C. Quettier-Deleu, B. Gressier, J. Vasseur et al., "Phenolic compounds and antioxidant activities of buckwheat (Fagopyrum esculentum Moench) hulls and flour," Journal of Ethnopharmacology, vol. 72, no. 1-2, pp. 35-42, 2000.

[35] G. Sadler, J. Davis, and D. Dezman, "Rapid extraction of lycopene and $\beta$-carotene from reconstituted tomato paste and pink grapefruit homogenates," Journal of Food Science, vol. 55, no. 5, pp. 1460-1461, 1990.

[36] M. Ozkan, Thermal Stability of Lycopene in Grapefruit Juice and Tomato Pulp at High Temperatures, Ankara University, Ankara, Turkey, 2006.

[37] W. Klunklin and G. Savage, "Effect on quality characteristics of tomatoes grown under well-watered and drought stress conditions," Foods, vol. 6, no. 8, pp. 56-65, 2017.

[38] B. Khanal, A. Suthaparan, A. B. Hückstädt, A. B. Wold, L. Mortensen, and H. R. Gislerød, "The effect of high day and low night temperature on pollen production, pollen germination and postharvest quality of tomatoes," American Journal of Plant Sciences, vol. 4, no. 7, pp. 19-25, 2013.

[39] R. Zhou, X. Yu, C.-O. Ottosen et al., "Drought stress had a predominant effect over heat stress on three tomato cultivars subjected to combined stress," BMC Plant Biology, vol. 17, no. 1, p. 24, 2017.

[40] K. S. Shivashankara, K. C. Pavithra, R. H. Laxman, A. T. Sadashiva, T. K. Roy, and M. G. Christopher, "Genotypic variability in tomato for total carotenoids and lycopene content during summer and response to post-harvest temperature," Journal of Horticultural Sciences, vol. 9, no. 1, pp. 98-102, 2014.

[41] A. N. Lokesha, K. S. Shivashankara, R. H. Laxman, G. A. Geetha, and A. G. Shankar, "Effect of high temperature on fruit quality parameters of contrasting tomato genotypes," International Journal of Current Microbiology and Applied Sciences, vol. 8, no. 3, pp. 1019-1029, 2019.

[42] C. Kaur, S. Walia, S. Nagal et al., "Functional quality and antioxidant composition of selected tomato (Solanum lycopersicon L) cultivars grown in northern India," LebensmittelWissenschaft und -Technologie-Food Science and Technology, vol. 50, no. 1, pp. 139-145, 2013.

[43] B. George, C. Kaur, D. S. Khurdiya, and H. C. Kapoor, "Antioxidants in tomato (Lycopersium esculentum) as a function of genotype," Food Chemistry, vol. 84, no. 1, pp. 45-51, 2004.

[44] H. D. Fleisher, S. L. Logendra, C. Moraru et al., "Effect of temperature perturbations on tomato (Lycopersicon esculentumMill.) quality and production scheduling," The Journal of Horticultural Science and Biotechnology, vol. 81, no. 1, pp. 125-131, 2006.

[45] B. Khanal, "Effect of day and night temperature on pollen characteristics, fruit quality and storability of tomato," Master's thesis, Department of Plant and Environmental
Sciences, Norwegian University of Life Sciences, Ås, Norway, 2012.

[46] M. A. F. Falah, T. Wajima, D. Yasutake, Y. Sago, and M. Kitano, "Responses of root uptake to high temperature of tomato plants (Lycopersicon esculentum Mill.) in soil-less culture," Journal of Agricultural Technology, vol. 6, no. 3, pp. 543-558, 2010.

[47] R. M. Rivero, J. M. Ruiz, P. C. Garcia, L. R. Lopez-Lefebre, E. Sanchez, and L. Romero, "Resistance to cold and heat stress: accumulation of phenolic compounds in tomato and watermelon plants," Plant Science, vol. 160, pp. 315-321, 2001.

[48] S. Weidner, M. Karolak, M. Karamać, A. Kosinska, and R. Amarowicz, "Phenolic compounds and properties of antioxidants in grapevine roots (Vitis vinifera L.) under drought stress followed by regeneration," Acta Societatis Botanicorum Poloniae, vol. 78, pp. 97-103, 2009.

[49] A. Król, R. Amarowicz, and S. Weidner, "Changes in the composition of phenolic compounds and antioxidant properties of grapevine roots and leaves (Vitis vinifera L.) under continuous of long-term drought stress," Acta Physiologiae Plantarum, vol. 36, pp. 1491-1499, 2014.

[50] R. K. Toor and G. P. Savage, "Changes in major antioxidant components of tomatoes during post-harvest storage," Food Chemistry, vol. 99, no. 4, pp. 724-727, 2006.

[51] Y. Akhoundnejad, Physiological and agricultural investigation of high temperature resistance in tomato, Ph.D. thesis, Cukurova University, Graduate School of Natural and Applied Sciences, Adana, Turkey, 2016.

[52] V. Hernández, P. Hellín, J. Fenoll, M. V. Molina, I. Garrido, and P. Flores, "Impact of high temperature stress on ascorbic acid concentration in tomato," Acta Horticulturae, vol. 1194, pp. 985-990, 2018.

[53] S. K. Sharma and M. Le Maguer, "Lycopene in tomatoes and tomato pulp fractions," Italian Journal of Food Science, vol. 8, no. 2, pp. 107-113, 1996.

[54] M. Z. Karipcin, S. Dinc, M. Kara, S. Kahraman, I. Alp, and H. Cicekci, "High temperature-tolerant tomato lines: bioactive compounds," Journal für Verbraucherschutz und Lebensmittelsicherheit, vol. 11, no. 2, pp. 117-125, 2016.

[55] E. Demiray, Y. Tulek, and Y. Yilmaz, "Degradation kinetics of lycopene, $\beta$-carotene and ascorbic acid in tomatoes during hot air drying," Lebensmittel-Wissenschaft und-Technologie-Food Science and Technology, vol. 50, no. 1, pp. 172-176, 2013.

[56] L. Helyes, A. Lugasi, and Z. Pék, "Effect of natural light on surface temperature and lycopene content of vine ripened tomato fruit," Canadian Journal of Plant Science, vol. 87, no. 4, pp. 927-929, 2007.

[57] J. Shi and M. L. Maguer, "Lycopene in tomatoes: chemical and physical properties affected by food processing," Critical Reviews in Food Science and Nutrition, vol. 40, no. 1, pp. 1-42, 2000.

[58] J. Sivakumar, J. E. P. Prashanth, N. Rajesh, S. M. Reddy, and O. B. Pinjari, "Principal component analysis approach for comprehensive screening of salt stress-tolerant tomato germplasm at the seedling stage," Journal of Biosciences, vol. 45, pp. 1-11, 2020.

[59] Q. Iqbal, M. Y. Saleem, A. Hameed, and M. Asghar, "Assessment of genetic divergence in tomato through agglomerative hierarchical clustering and principal component analysis," Pakistan Journal of Botany, vol. 46, pp. 1865-1870, 2014. 